\title{
Synthesis of tetramethoxy-(tetra-hydrazinecarboxamide) cyclophanes with unexpected conformation, and investigation of their solution-phase recognition of chiral carboxylic guests using time-of-flight and tandem mass spectrometry
}

\author{
Hany F. Nour, ${ }^{* a}$ Agnieszka Golon, $^{b}$ Tamer El Malah, ${ }^{a}$ and Nikolai Kuhnert ${ }^{* b}$ \\ ${ }^{a}$ National Research Centre, Department of Photochemistry, El Behoose Street, \\ PO Box 12622, Cairo, Dokki, Egypt \\ ${ }^{b}$ Jacobs University Bremen, School of Engineering and Science, Laboratory of Organic \\ and Analytical Chemistry, D-28759, Bremen, Germany \\ E-mail: hany.nour@daad-alumni.de, n.kuhnert@jacobs-university.de
}

DOI: http://dx.doi.org/10.3998/ark.5550190.p008.875

\begin{abstract}
New tetramethoxy-(tetra-hydrazinecarboxamide) cyclophanes with unexpected antilanti conformation were prepared from the addition of chiral dioxolane-based dicarbohydrazides to $4,4^{\prime}$-diisocyanato-3,3'-dimethoxy-1,1'-biphenyl in anhydrous THF. The molecular recognition of the macrocycles to a selection of chiral carboxylic guests, i.e., L-(+)-tartaric, D-(-)-tartaric, D-(-)quinic, L-(-)-malic, D-(+)-galacturonic and D-glucuronic acids, was investigated by using direct injection electrospray ionization time-of-flight (ESI-TOF) and tandem mass spectrometry. A series of 1,3-dioxolane-4,5-dicarbonyl-bis-( $N$-substituted)-hydrazinecarboxamides, which mimic the backbone structure of the new cyclophanes, were also synthesized by addition of dioxolane dicarbohydrazides to aromatic isocyanates and their complexation with the aforementioned carboxylic guests was investigated by using direct injection ESI-TOF MS and MS/MS.
\end{abstract}

Keywords: Tetramethoxy-(tetra-hydrazinecarboxamide) cyclophane, macrocycle, molecular recognition, carboxylic guest, ESI-TOF MS, MS/MS

\section{Introduction}

Molecular recognition has been given considerable attention during the past several decades. ${ }^{1,2}$ It refers to the interactions taking place between two or more molecules via noncovalent bonds, such as hydrogen bonds (H-bonds), metal coordination, van der Waals and hydrophobic forces or $\pi-\pi$ stacking. Most of the biological processes occurring within the human body rely mainly on recognition, such as ligand-protein, DNA-protein and RNA-protein interactions. ${ }^{3-5}$ Nature is rich 
in examples which demonstrate the concept of molecular recognition. The earliest model was the Emil Fischer "lock and key" principle for the recognition of the enzymes and substrates. ${ }^{6}$ Molecular recognition directed self-organization of supramolecular architectures is one of the most fundamental topics of supramolecular chemistry. ${ }^{7,8}$ It is the driving force for the assembly of the tobacco mosaic virus (TMV) to a helical supramolecular polymer. ${ }^{9,10}$ TMV builds its structure in an extremely precise process in which 2130 identical protein subunits assemble around a single strand of the viral RNA. Another important example is the recognition of the antibiotic vancomycin to the peptide sequence D-Ala-D-Ala in the bacterial cell-wall. ${ }^{11}$ The molecular recognition takes place via formation of noncovalent bonds between the antibiotic hepta-peptide backbone and the peptide precursor of the cell-wall. Molecular recognition of carboxyl-containing guests by receptors of different architectures has attracted wide interest due to their presence in a variety of biomolecules. It offers opportunities for developing therapeutic agents or designing of new chemical sensors. ${ }^{11,12}$ The majority of molecular recognition studies to date have focused on interactions in solution whereas the results are highly influenced by the reaction medium. However, the study of molecular recognition has been successfully taken into the gas-phase and showed great promise. ${ }^{13,14}$ Mass spectrometry (MS) has been extensively employed in studying noncovalent interactions. ${ }^{15-17}$ The detection of host/guest (Ht/Gt) complexes by MS became feasible with the development of soft ionization techniques, such as fast atom bombardment (FAB), matrix-assisted laser desorption ionization (MALDI) and electrospray ionization (ESI). ${ }^{18-20}$ The ability of electrospray ionization time-of-flight mass spectrometry (ESI-TOF MS) to provide precise mass values, rapid screening and very little consumption of samples, makes it an indispensible tool in supramolecular analysis. Moreover, MS can provide vital information about the complex stoichiometry between hosts and guests. In modern MS techniques, the molecular ions of interest can be trapped and allowed to undergo collision with an inert reagent gas to induce dissociation. Recently, ESI-TOF MS has been used as an effective tool in studying short-lived intermediates formed in solution. ${ }^{21,22}$ The real-time observation of such intermediates provides crucial insight into the reaction mechanisms. We probed the stepwise reaction mechanism of trianglimine formation in real-time by using ESI-TOF MS and detected all the reactive intermediates forming the macrocycles. ${ }^{23}$ Recently, we reported the synthesis of novel chiral tetra-(carbohydrazide) and tetra-(hydrazinecarboxamide) cyclophanes from the reactions of chiral tartaric-based dicarbohydrazides with aromatic dialdehydes and diisocyanates, taking advantage of the commercial availability of tartaric acid in both enantiomeric forms $(R$ and $S) .{ }^{24,25}$ Similar to the case of trianglimines, the cyclophane macrocycles were formed under conformational bias of the dicarbohydrazide precursors in a chemoselective [2+2] macrocyclization reaction. ${ }^{26-33}$ The tetra-(carbohydrazide) cyclophanes underwent dynamic exchange and formed dynamic combinatorial libraries (DCLs) of interconverting species. ${ }^{34}$ Some members in the DCL formed stable Ht/Gt complexes with oligopeptides, which mimic the backbone structure of the bacterial cell-wall. In this study, we investigated the effect of varying the geometry of the isocyanate moieties, in the diisocyanate component, on the products from the macrocyclization reaction. We also assessed the molecular recognition affinity of the new 
cyclophanes to a selection of chiral carboxylic guests by using direct injection ESI-TOF MS and MS/MS. The experimental data were further rationalized by the results of the Austin Model 1 (AM1) molecular modeling calculations. ${ }^{35,36}$

\section{Results and Discussion}

\section{Synthesis and conformational analysis}

Recently, we reported the synthesis of a new class of chiral $C_{2}$-symmetrical macrocycles, named tetra-(hydrazinecarboxamide) cyclophanes, in a [2+2] macrocyclization reaction. ${ }^{25}$ The reaction took place through addition of chiral dioxolane-based dicarbohydrazides to aromatic diisocyanates under conformational bias of the dicarbohydrazide precursors. Both $(R)$ and $(S)$ enantiomers can be readily obtained in high yields as sufficiently pure products. In this contribution, we discuss the synthesis of new oxygenated tetra-(hydrazinecarboxamide) cyclophanes with unexpected anti/anti orientation of the amide functionalities and assess their solution-phase recognition to a selection of carboxylic guests by using direct injection ESI-TOF MS and MS/MS. Macrocycles 9-13 were prepared by addition of the dioxolane dicarbohydrazides 1-5 to 4,4'diisocyanato-3,3'-dimethoxy-1,1'-biphenyl 6 (Figure 1). The ${ }^{1} \mathrm{H}$ NMR spectra of the new macrocycles 9-13 are consistent with regular $C_{2}$-symmetric structures. The ${ }^{1} \mathrm{H}$ NMR spectrum of macrocycle 11 showed three broad signals at $\delta 10,8.7$ and $8.1 \mathrm{ppm}$, corresponding to the twelve $\mathrm{N} H$ protons. The FT-IR spectrum showed two characteristic absorption bands at $v 3276$ and 1681 $\mathrm{cm}^{-1}$ for the $\mathrm{NH}$ and $\mathrm{CO}$ moieties, respectively. 


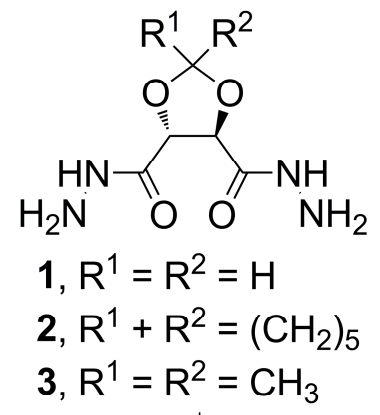

$$
3, \mathrm{R}^{1}=\mathrm{R}^{2}=\mathrm{CH}_{3}
$$

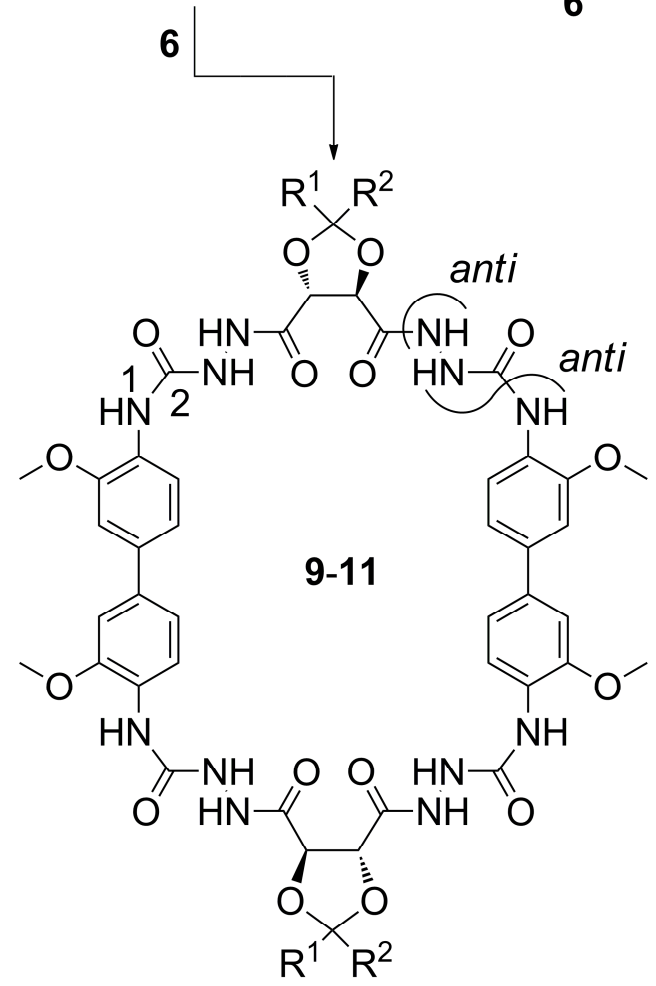

$$
\begin{aligned}
& \text { 9, } R^{1}=R^{2}=H \\
& \text { 10, } R^{1}+R^{2}=\left(\mathrm{CH}_{2}\right)_{5} \\
& \text { 11, } R^{1}=R^{2}=\mathrm{CH}_{3}
\end{aligned}
$$

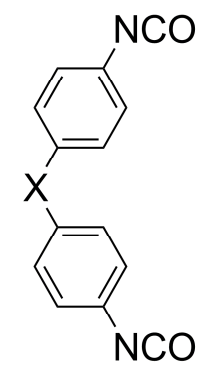<smiles>[R]C1([R])O[C@H](C(N)=O)[C@H](C(N)=O)O1</smiles>

$$
\begin{aligned}
& \text { 4, } R^{1}=R^{2}=H \\
& 5, R^{1}=R^{2}=\mathrm{CH}_{3}
\end{aligned}
$$

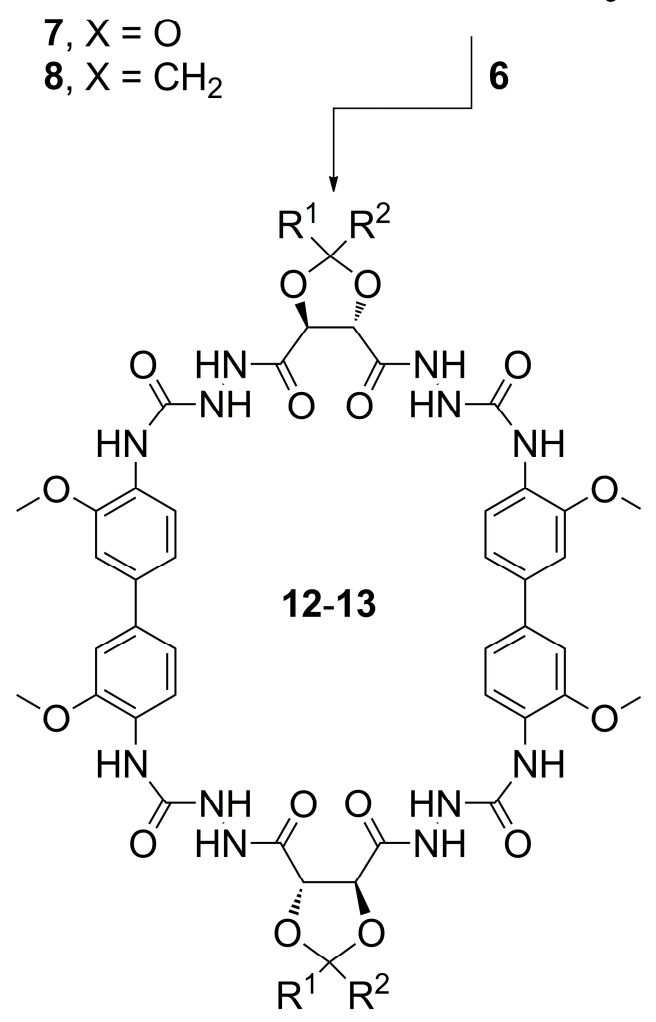

12, $\mathrm{R}^{1}=\mathrm{R}^{2}=\mathrm{H}$

13, $\mathrm{R}^{1}=\mathrm{R}^{2}=\mathrm{CH}_{3}$

Figure 1. Structures and conformation of the $[2+2]$ macrocyclization products 9-13.

The ESI-TOF mass spectrum, in the positive ion mode, afforded a peak at $\mathrm{m} / \mathrm{z} 1051.3$ for the sodium adduct of macrocycle 11 (Figure 2 and Table 1). It is noteworthy that the cyclophane macrocycles, which were obtained by addition of the dioxolane dicarbohydrazides 1-5 to either 4,4'-oxybis(isocyanatobenzene) 7 or bis(4-isocyanatophenyl)methane $\mathbf{8}$ adopted a syn/anti conformation, which was stabilized by two intramolecular $\mathrm{H}$-bonds $\left(\mathrm{N} H^{\cdots} \mathrm{CO}\right){ }^{25}$ The isocyanate moieties in the aforementioned diisocyanates form a dihedral angle less than $180^{\circ}$. The [2+2] macrocycles were selectively formed as solo products from the addition of dicarbohydrazides 1-5 to diisocyanates $\mathbf{7}$ and $\mathbf{8}$. 


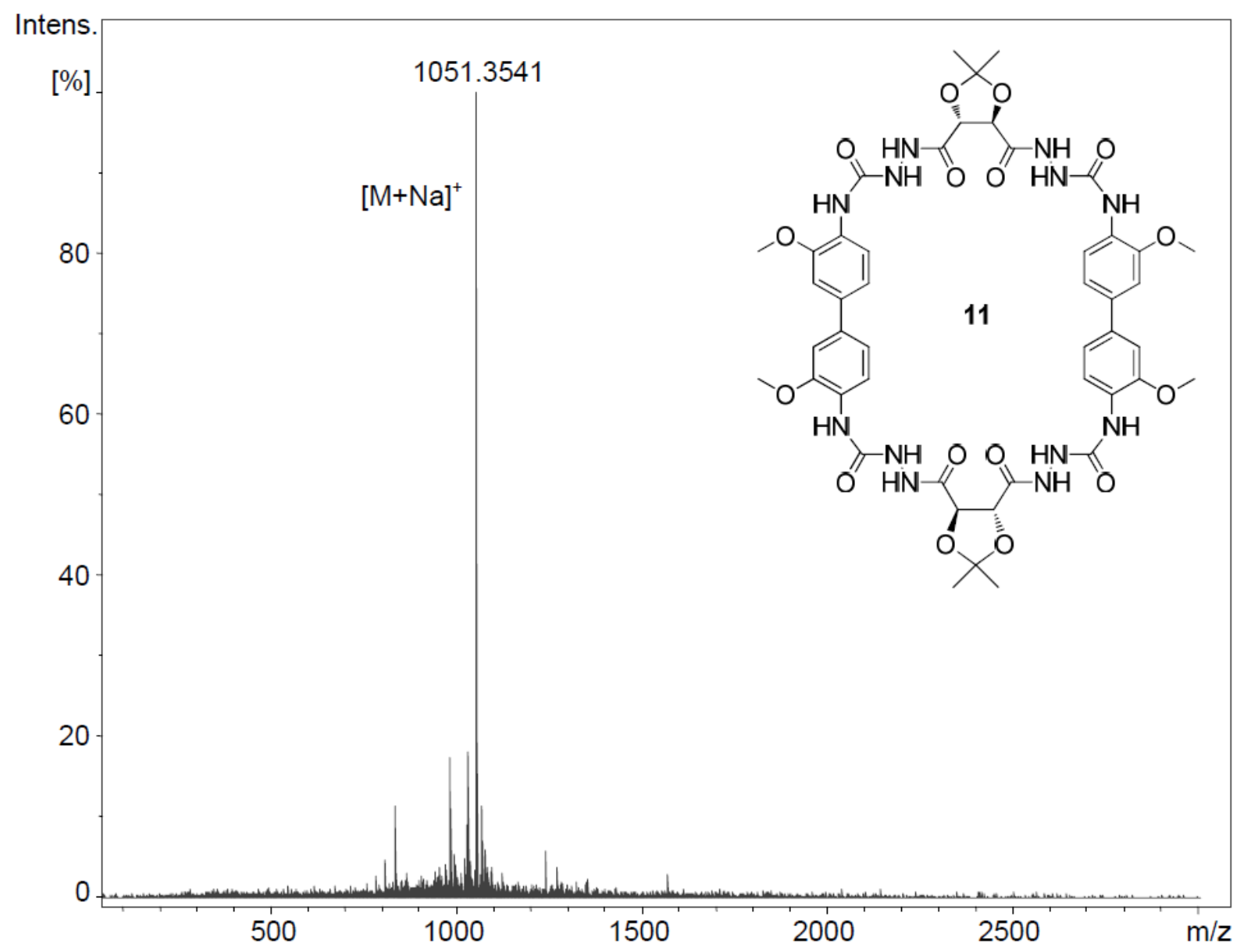

Figure 2. ESI-TOF MS of macrocycle 11, DMF/CH $3 \mathrm{CN}_{3}[\mathrm{M}+\mathrm{Na}]^{+}$.

Macrocycles or oligomers with higher molecular weights (MWs) were not observed as products from the addition reaction. In the case of trianglimine macrocycles, the geometry of the carbonyl moieties in the dialdehyde precursors determines to a large extent the types of product from the cyclocondensation reaction. Dialdehydes with dihedral angles less than $180^{\circ}$ give a mixture of the [2+2] and [3+3] cyclocondensation products upon reaction with trans- $(1 R, 2 R)-$ 1,2-diaminocyclohexane. ${ }^{28}$ The [3+3] macrocycles form selectively in cases where the dihedral angle between the carbonyl moieties equals $180^{\circ}$. We expected formation of high MW macrocycles by addition of the dioxolane dicarbohydrazides 1-5 to diisocyanate 6 in which the dihedral angle between the two isocyanate moieties is $180^{\circ}$. However, the [2+2] macrocycles were the only products to be obtained from this reaction as confirmed by ESI-TOF MS and MS/MS. In this particular case, formation of the [2+2] macrocycles must be accompanied by conformational change of the $\mathrm{NH}$ moieties. Interestingly, the 2D ROESY NMR spectra of the new macrocycles showed no through space interactions between $\mathrm{N} H^{1}-\mathrm{N} H^{3}$ and $\mathrm{NH}^{3}-\mathrm{N} H^{4}$, which suggested an antilanti orientation of the $\mathrm{NH}$ moieties (Fig's 1 and 3). It also showed no cross peak correlations 
between the $\mathrm{N} H$ moieties and the aromatic or the methoxy protons, which suggested that the four methoxy moieties point outwards with respect to the cavity of the macrocycles.

Table 1. HRMS data of compounds 9-21

\begin{tabular}{ccccccc}
\hline Cpd. & MF & Calcd. $m / z$ & \multicolumn{2}{c}{ Meas. $m / z$} & \multicolumn{2}{c}{ Error (ppm) Yield(\%) } \\
\hline $\mathbf{9}^{a}$ & $\mathrm{C}_{42} \mathrm{H}_{44} \mathrm{~N}_{12} \mathrm{O}_{16}$ & 973.3071 & 973.3059 & {$[\mathrm{M}+\mathrm{H}]^{+}$} & -1.3 & 94 \\
$\mathbf{1 0}^{a}$ & $\mathrm{C}_{52} \mathrm{H}_{60} \mathrm{~N}_{12} \mathrm{O}_{16}$ & 1109.4323 & 1109.4335 & {$[\mathrm{M}+\mathrm{H}]^{+}$} & +1.1 & 88 \\
$\mathbf{1 1}^{a}$ & $\mathrm{C}_{46} \mathrm{H}_{52} \mathrm{~N}_{12} \mathrm{O}_{16}$ & 1051.3516 & 1051.3541 & {$[\mathrm{M}+\mathrm{Na}]^{+}$} & +2.3 & 78 \\
$\mathbf{1 2}^{a}$ & $\mathrm{C}_{42} \mathrm{H}_{44} \mathrm{~N}_{12} \mathrm{O}_{16}$ & 973.2925 & 973.2945 & {$[\mathrm{M}+\mathrm{H}]^{+}$} & +2.1 & 90 \\
$\mathbf{1 3}^{b}$ & $\mathrm{C}_{46} \mathrm{H}_{52} \mathrm{~N}_{12} \mathrm{O}_{16}$ & 1027.3551 & 1027.3588 & {$[\mathrm{M}-\mathrm{H}]^{-}$} & +3.6 & 76 \\
$\mathbf{1 4}^{b}$ & $\mathrm{C}_{23} \mathrm{H}_{28} \mathrm{~N}_{6} \mathrm{O}_{10}$ & 547.1794 & 547.1816 & {$[\mathrm{M}-\mathrm{H}]^{-}$} & +4.0 & 87 \\
$\mathbf{1 5}^{b}$ & $\mathrm{C}_{31} \mathrm{H}_{28} \mathrm{~N}_{6} \mathrm{O}_{8}$ & 611.1896 & 611.1920 & {$[\mathrm{M}-\mathrm{H}]^{-}$} & +4.0 & 99 \\
$\mathbf{1 6}^{b}$ & $\mathrm{C}_{23} \mathrm{H}_{28} \mathrm{~N}_{6} \mathrm{O}_{8}$ & 515.1896 & 515.1878 & {$[\mathrm{M}-\mathrm{H}]^{-}$} & -3.5 & 81 \\
$\mathbf{1 7}^{b}$ & $\mathrm{C}_{33} \mathrm{H}_{32} \mathrm{~N}_{6} \mathrm{O}_{6}$ & 607.2311 & 607.2308 & {$[\mathrm{M}-\mathrm{H}]^{-}$} & -0.4 & 99 \\
$\mathbf{1 8}^{b}$ & $\mathrm{C}_{27} \mathrm{H}_{36} \mathrm{~N}_{6} \mathrm{O}_{10}$ & 603.2420 & 603.2419 & {$[\mathrm{M}-\mathrm{H}]^{-}$} & -0.2 & 85 \\
$\mathbf{1 9}^{b}$ & $\mathrm{C}_{23} \mathrm{H}_{28} \mathrm{~N}_{6} \mathrm{O}_{10}$ & 547.1794 & 547.1784 & {$[\mathrm{M}-\mathrm{H}]^{-}$} & -1.8 & 71 \\
$\mathbf{2 0}^{b}$ & $\mathrm{C}_{31} \mathrm{H}_{28} \mathrm{~N}_{6} \mathrm{O}_{8}$ & 611.1896 & 611.1873 & {$[\mathrm{M}-\mathrm{H}]^{-}$} & -3.7 & 88 \\
$\mathbf{2 1}^{b}$ & $\mathrm{C}_{23} \mathrm{H}_{28} \mathrm{~N}_{6} \mathrm{O}_{8}$ & 515.1896 & 515.1872 & {$[\mathrm{M}-\mathrm{H}]^{-}$} & -4.7 & 73 \\
\hline
\end{tabular}

(a) Positive ion mode, $(b)$ negative ion mode.

Tetra-(hydrazinecarboxamide) cyclophane macrocycles can accordingly be prepared in a stable and isolable syn/anti or anti/anti conformation by simple variation of the dihedral angle between the isocyanate moieties in the diisocyanate precursor. Switching the conformation of a macrocycle from one form to another is common and can be induced by addition of an external stimulus, such as an anion, which binds preferentially to one form and stabilizes it. ${ }^{37,38}$ An example of anion-induced conformational change of a macrocycle is the isophthalic acid-based macrocyclic tetra-amides. ${ }^{38}$ The tetra-amide macrocycles adopt a syn/anti conformation, which is stabilized by two intramolecular H-bonds. Addition of an anion breaks the H-bonds and switches the conformation to all-syn. The new cyclophanes 9-13 constitute an interesting example of conformational dependence of the macrocycles on the geometry of their precursors. The openframework compounds 14-21, which mimic the backbone structure of macrocycles 9-13, were prepared by addition of $(4 R, 5 R)$ - or $(4 S, 5 S)$-1,3-dioxolane-4,5-dicarbohydrazides $\mathbf{1}$ and $\mathbf{4}$ to substituted aromatic isocyanates (Figure 4). The ${ }^{1} \mathrm{H}$ NMR spectrum of compound $\mathbf{1 4}$ showed three broad signals at $\delta 10,8.7$ and $8.1 \mathrm{ppm}$, corresponding to the six NH protons. The FT-IR 
spectrum showed the expected absorption bands of the $\mathrm{NH}$ and $\mathrm{CO}$ moieties at $v 3326$ and 1655 $\mathrm{cm}^{-1}$, respectively.

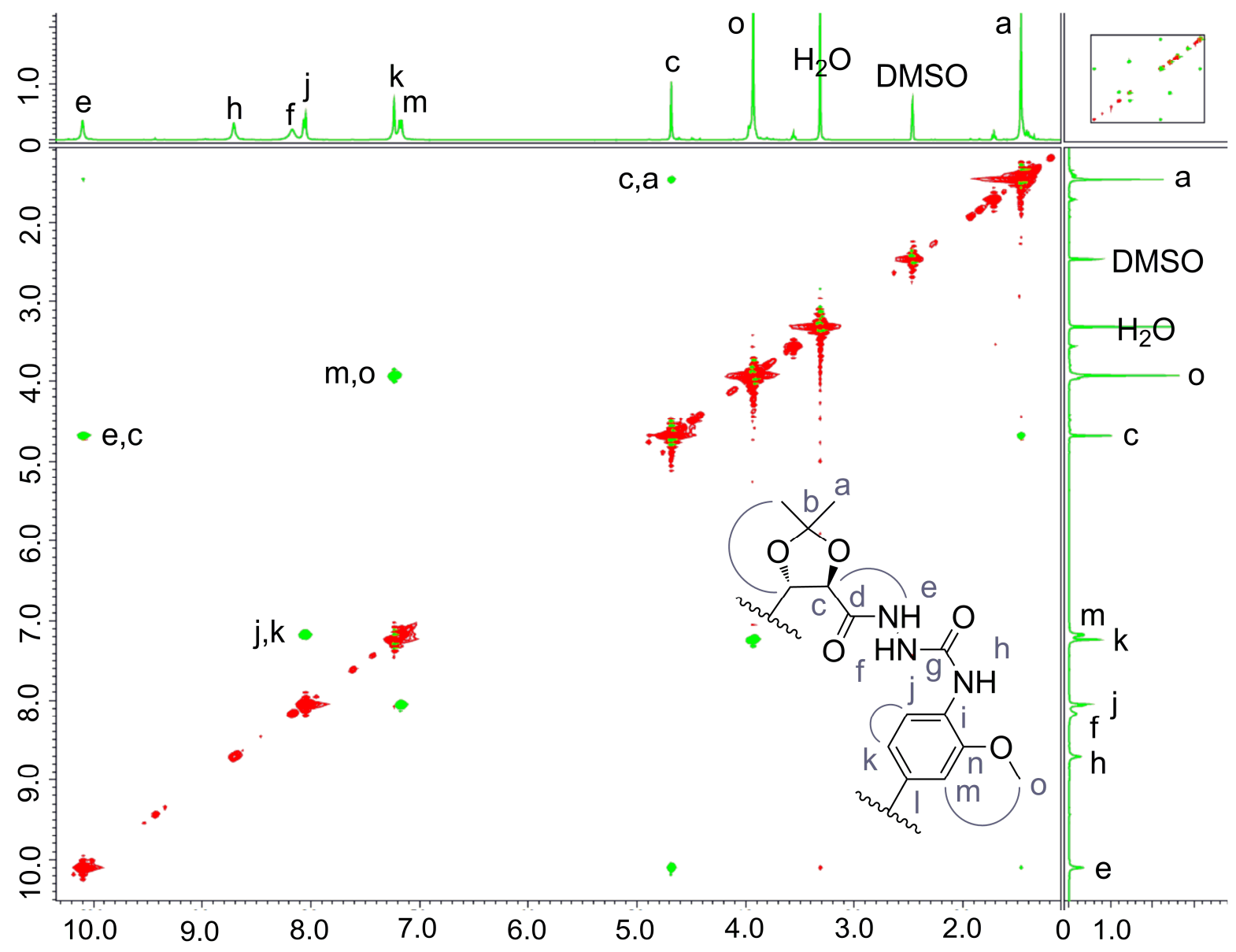

Figure 3. 2D ROESY NMR spectrum of macrocycle 11 in DMSO- $d_{6}$.

The ESI-TOF MS showed the expected molecular ion peak at $m / z 547.1$ as $[\mathrm{M}-\mathrm{H}]^{-}$. The $\mathrm{N} H$ moieties in the open-framework compounds 14-21 adopted a syn/syn conformation. The 2D ROESY NMR spectrum of $\mathbf{1 4}$ showed cross peak interactions between $\mathrm{N} H^{3}-\mathrm{N} H^{4}$ and $\mathrm{N} H^{4}-\mathrm{N} H^{6}$. The syn/syn conformer is stabilized by two intramolecular $\mathrm{H}$-bonds forming between $\mathrm{NH}^{3^{\prime} \cdots \mathrm{CO}^{5}}$ and $\mathrm{NH}^{3 \cdots} \mathrm{CO}^{5^{\prime}}$. The stacked variable temperature NMR spectra (VT NMR) of 14 in DMSO- $d_{6}$ showed downfield shifts of the $\mathrm{NH}$ protons on heating as a consequence of breaking the intramolecular H-bonds (see the Supporting Information).

\section{Investigation of solution-phase recognition by using mass spectrometry}

ESI-TOF MS is found to be a powerful technique in the analysis of $\mathrm{Ht} / \mathrm{Gt}$ complexes formed in solution. ${ }^{15,17}$ It has been widely used in examining both inter- and intramolecular noncovalent interactions. With soft ionization techniques, such as ESI, these interactions can be preserved. 
An important advantage of using ESI-TOF MS in studying noncovalent interactions is the absence of the competing effects of the solvents. Another feature of ESI-TOF MS and MS/MS is the ability to provide precise information about the stoichiometry of the species forming the supramolecular complexes in the gas-phase and to gain more insight into the mechanism of their assembly. Thus, by using a suitable soft ionization source, the observed molecular ion peaks will correspond to the sum of the MWs of the individual species, if two or more molecules assemble in solution and transfer into the gas phase. In the MS/MS experiments, the ions of interest can be trapped and dissociated by collision energy. As the energy increases, the $\mathrm{Ht} / \mathrm{Gt}$ complexes can be dissociated into their individual constituents.
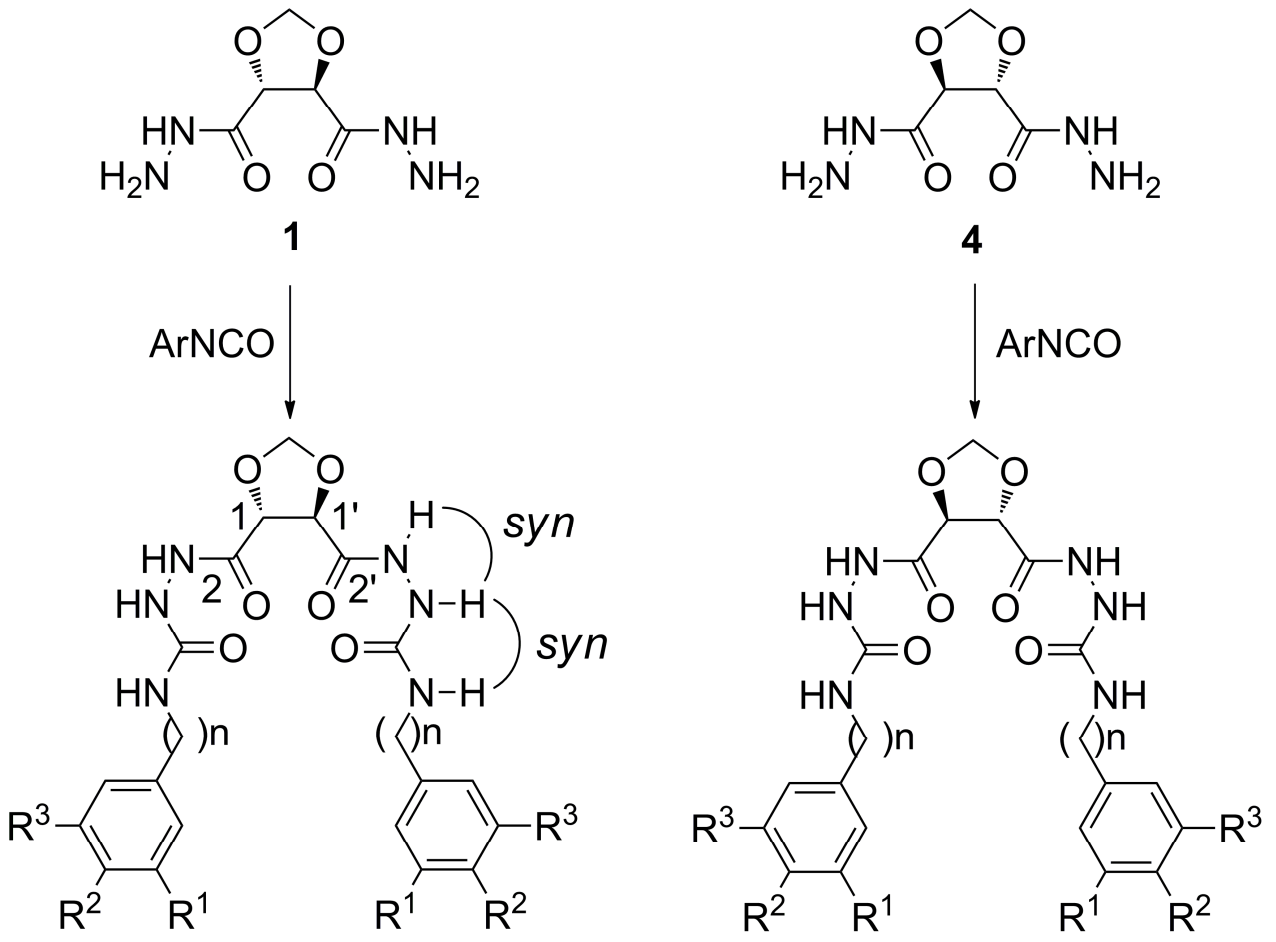
14, $\mathrm{R}^{1}=\mathrm{R}^{3}=\mathrm{OCH}_{3}, \mathrm{R}^{2}=\mathrm{H}, \mathrm{n}=0$
19, $\mathrm{R}^{1}=\mathrm{R}^{3}=\mathrm{OCH}_{3}, \mathrm{R}^{2}=\mathrm{H}, \mathrm{n}=0$
15, $R^{1}=R^{3}=H, R^{2}=O P h, n=0$
20, $R^{1}=R^{3}=H, R^{2}=O P h, n=0$
16, $R^{1}=R^{3}=H, R^{2}=O M e, n=1$
21, $R^{1}=R^{3}=H, R^{2}=$ OMe, $n=1$
$17, \mathrm{R}^{1}=\mathrm{R}^{3}=\mathrm{H}, \mathrm{R}^{2}=\mathrm{CH}_{2} \mathrm{Ph}, \mathrm{n}=0$
18, $R^{1}=H, R^{2}=R^{3}=$ OMe, $n=2$

Figure 4. Structures and conformation of compounds 14-21.

Macrocycles 9-13 formed stable 1:1 Ht/Gt complexes with the chiral carboxylic guests 2227. The high resolution mass spectrometry (HRMS) data of the Ht/Gt complexes 11/22-27 and 14/22-27 are shown in Table 2. The ESI-TOF MS of complex 11/22 showed a Ht/Gt peak at $\mathrm{m} / \mathrm{z}$ 1177.3. It gave on dissociation a base peak at $\mathrm{m} / \mathrm{z} 1028.3$ for the protonated macrocycle 11 (see 
Figure 5a and the Supporting Information). Interestingly, macrocycle 11 showed propensity to incorporate two molecules of D-glucuronic acid 27. The ESI-TOF MS of complex 11/27 showed an intense peak at $\mathrm{m} / \mathrm{z}$ 1221.3, corresponding to the $1: 1 \mathrm{Ht} / \mathrm{Gt}$ complex 11/27 $\left[\left(\mathrm{M}^{11}+\mathrm{M}^{27}\right)-\mathrm{H}\right]^{-}$. It showed also a less intense peak at $m / z$ 1415.4 for the 1:2 Ht/Gt complex 11/27 $\left[\left(\mathrm{M}^{11}+2 \mathrm{M}^{27}\right)-\mathrm{H}\right]^{-}$ (see the Supporting Information). Tetra-(hydrazinecarboxamide) cyclophanes with a syn/anti conformation, which were prepared from dioxolanes 1-5 and diisocyanates $\mathbf{7}$ and $\mathbf{8}$, formed stable Ht/Gt complexes with carboxylic guests as similar to macrocycles 9-13. ${ }^{39}$ On the other hand, the open-framework compounds 14-21, which mimic the backbone structure of macrocycles 9-13, exhibited molecular self-assembly at high concentrations in $\mathrm{CH}_{3} \mathrm{CN} / \mathrm{DMF}{ }^{40}$ The ESI-TOF MS of compound 18 showed four peaks at $\mathrm{m} / \mathrm{z} 627.3,1231.5,1835.9$ and 2441.2, corresponding to the sodiated monomeric, dimeric, trimeric and tetrameric supramolecular aggregates. The ESI-MS/MS of the trimeric complex gave a base peak at $\mathrm{m} / \mathrm{z} 627.1$ for the sodiated monomer and an intense peak at $\mathrm{m} / \mathrm{z} 1231.4$ for the sodiated dimer (see the Supporting Information). Compounds 14-21 formed structurally unique self-assembled aggregates upon mixing with guests 22-27. ${ }^{40}$ We expected formation of $1: 1$ and 2:1 Ht/Gt complexes. However, the compounds formed assembled aggregates of the type and order $[(n \mathrm{Ht}+\mathrm{Gt})-\mathrm{H}]^{-}(n=1-4)$, which were lined up in a row-like structure and bonded together via intermolecular H-bonds. ${ }^{40}$

The ESI-TOF MS of the Ht/Gt complex 14/22 showed six intense peaks at $m / z$ 547.1, 697.1, 1095.3, 1245.3, 1793.5 and 2342.7, corresponding to $\left[\mathrm{M}^{14}-\mathrm{H}\right]^{-},\left[\left(\mathrm{M}^{14}+\mathrm{M}^{22}\right)-\mathrm{H}\right]^{-},\left[2 \mathrm{M}^{14}-\mathrm{H}\right]^{-}$, $\left[\left(2 \mathrm{M}^{14}+\mathrm{M}^{22}\right)-\mathrm{H}\right]^{-},\left[\left(3 \mathrm{M}^{14}+\mathrm{M}^{22}\right)-\mathrm{H}\right]^{-}$and $\left[\left(4 \mathrm{M}^{14}+\mathrm{M}^{22}\right)-\mathrm{H}\right]^{-}$, respectively (see Figure $5 \mathrm{~b}$ and Table 2). ESI-MS/MS was employed to determine the exact binding mode between the assembled associations of the $\mathrm{Ht} / \mathrm{Gt}$ complex 14/22. The peak with $\mathrm{m} / \mathrm{z} 1245.3$ dissociates to give three peaks at $m / z$ 547, 697 and 1095.3, corresponding to $\left[\mathrm{M}^{14}-\mathrm{H}\right]^{-},\left[\left(\mathrm{M}^{14}+\mathrm{M}^{22}\right)-\mathrm{H}\right]^{-}$and $\left[2 \mathrm{M}^{14}-\mathrm{H}\right]^{-}$ (base peak), respectively. Observation of a base peak at $\mathrm{m} / \mathrm{z} 1095.3$ is clear evidence that the assembly takes place in the order $\left(\mathrm{Ht}^{14} / \mathrm{Ht}^{14} / \mathrm{Gt}^{22}\right)$ and not $\left(\mathrm{Ht}^{14} / \mathrm{Gt}^{22} / \mathrm{Ht}^{14}\right)$. Assembly in the order $\left(\mathrm{Ht}^{14} / \mathrm{Gt}^{22} / \mathrm{Ht}^{14}\right)$ was not taken into consideration because the MS/MS of this complex could never give a peak corresponding to the $\left[2 \mathrm{M}^{14}-\mathrm{H}\right]^{-}$complex. The tandem mass spectrum of the $\mathrm{Ht} / \mathrm{Ht}$ and $\mathrm{Ht} / \mathrm{Gt}$ complexes with $m / z 1095.3\left[2 \mathrm{M}^{14}-\mathrm{H}\right]^{-}$and $697\left[\left(\mathrm{M}^{14}+\mathrm{M}^{22}\right)-\mathrm{H}\right]^{-}$gave a base peak at $m / z 547$, corresponding to $\left[\mathrm{M}^{14}-\mathrm{H}\right]^{-}$. Another example, which confirms assembly in the order $[(n \mathrm{Ht}+\mathrm{Gt})-\mathrm{H}]^{-}$is the assembly of the Ht/Gt complex 14/27. The ESI-TOF MS of this complex showed five peaks appearing at $\mathrm{m} / \mathrm{z}$ 547.1, 741.2, 1095.3, 1289.3 and 1837.5, corresponding to $\left[\mathrm{M}^{14}-\mathrm{H}\right]^{-},\left[\left(\mathrm{M}^{14}+\mathrm{M}^{27}\right)-\mathrm{H}\right]^{-},\left[2 \mathrm{M}^{14}-\mathrm{H}\right]^{-},\left[\left(2 \mathrm{M}^{14}+\mathrm{M}^{27}\right)-\mathrm{H}\right]^{-}$and $\left[\left(3 \mathrm{M}^{14}+\mathrm{M}^{27}\right)-\mathrm{H}\right]^{-}$complexes, respectively (see Table 2 and the Supporting Information). The ESI-MS/MS of the complex with $m / z$ 1289.3, in the negative ion mode, afforded three peaks at $m / z 547,741.1$ and 1095.3 (base peak), corresponding to $\left[\left(\mathrm{M}^{14}\right)-\mathrm{H}\right]^{-},\left[\left(\mathrm{M}^{14}+\mathrm{M}^{27}\right)-\mathrm{H}\right]^{-}$and $\left[\left(2 \mathrm{M}^{14}\right)-\mathrm{H}\right]^{-}$, respectively. The detection of a mass peak of $m / z 1095.3$ confirms assembly in the order $\left(\mathrm{Ht}^{14} / \mathrm{Ht}^{14} / \mathrm{Gt}^{27}\right)$. Further ESI-TOF MS and tandem MS experiments of the assembled Ht/Gt associations are shown in the Supporting Information. 
Table 2. ESI-TOF MS data of the Ht/Gt complexes 11/22-27 and 14/22-27 in the negative ion mode

\begin{tabular}{|c|c|c|c|c|c|}
\hline Guest & \multirow{2}{*}{ M.F. } & \multirow{2}{*}{$\begin{array}{c}\text { Calc. } m / z \\
1177.3716\end{array}$} & \multicolumn{2}{|c|}{ Found $m / z$} & $\begin{array}{l}\text { Error } \\
(\mathrm{ppm})\end{array}$ \\
\hline & & & 1177.3740 & ${ }^{a}\left[\left(\mathrm{M}^{11}+\mathrm{M}^{22}\right)-\mathrm{H}\right]^{-}$ & +2.0 \\
\hline & $\mathrm{C}_{27} \mathrm{H}_{34} \mathrm{~N}_{6} \mathrm{O}_{16}$ & 697.1959 & 697.1986 & ${ }^{b}\left[\left(\mathrm{M}^{14}+\mathrm{M}^{22}\right)-\mathrm{H}\right]^{-}$ & +4.0 \\
\hline & $\mathrm{C}_{46} \mathrm{H}_{56} \mathrm{~N}_{12} \mathrm{O}_{20}$ & 1095.3661 & 1095.3655 & ${ }^{b}\left[\left(2 \mathrm{M}^{14}\right)-\mathrm{H}\right]^{-}$ & -0.6 \\
\hline & $\mathrm{C}_{50} \mathrm{H}_{62} \mathrm{~N}_{12} \mathrm{O}_{26}$ & 1245.3825 & 1245.3796 & ${ }^{b}\left[\left(2 \mathrm{M}^{14}+\mathrm{M}^{22}\right)-\mathrm{H}\right]^{-}$ & -2.4 \\
\hline & $\mathrm{C}_{73} \mathrm{H}_{90} \mathrm{~N}_{18} \mathrm{O}_{36}$ & 1793.5692 & 1793.5668 & ${ }^{b}\left[\left(3 \mathrm{M}^{14}+\mathrm{M}^{22}\right)-\mathrm{H}\right]^{-}$ & -1.3 \\
\hline & $\mathrm{C}_{50} \mathrm{H}_{58} \mathrm{~N}_{12} \mathrm{O}_{22}$ & 1177.3716 & 1177.3728 & ${ }^{a}\left[\left(\mathrm{M}^{11}+\mathrm{M}^{23}\right)-\mathrm{H}\right]^{-}$ & +1.1 \\
\hline & $\mathrm{C}_{27} \mathrm{H}_{34} \mathrm{~N}_{6} \mathrm{O}_{16}$ & 697.1959 & 697.1934 & ${ }^{b}\left[\left(\mathrm{M}^{14}+\mathrm{M}^{23}\right)-\mathrm{H}\right]^{-}$ & -3.6 \\
\hline & $\mathrm{C}_{46} \mathrm{H}_{56} \mathrm{~N}_{12} \mathrm{O}_{20}$ & 1095.3661 & 1095.3633 & ${ }^{b}\left[\left(2 \mathrm{M}^{14}\right)-\mathrm{H}\right]^{-}$ & -2.6 \\
\hline & $\mathrm{C}_{50} \mathrm{H}_{62} \mathrm{~N}_{12} \mathrm{O}_{26}$ & 1245.3825 & 1245.3808 & ${ }^{b}\left[\left(2 \mathrm{M}^{14}+\mathrm{M}^{23}\right)-\mathrm{H}\right]^{-}$ & -1.4 \\
\hline & $\mathrm{C}_{73} \mathrm{H}_{90} \mathrm{~N}_{18} \mathrm{O}_{36}$ & 1793.5692 & 1793.5679 & ${ }^{b}\left[\left(3 \mathrm{M}^{14}+\mathrm{M}^{23}\right)-\mathrm{H}\right]^{-}$ & -0.8 \\
\hline & $\mathrm{C}_{53} \mathrm{H}_{64} \mathrm{~N}_{12} \mathrm{O}_{22}$ & 1219.4185 & 1219.4170 & ${ }^{a}\left[\left(\mathrm{M}^{11}+\mathrm{M}^{24}\right)-\mathrm{H}\right]^{-}$ & -1.1 \\
\hline & $\mathrm{C}_{30} \mathrm{H}_{40} \mathrm{~N}_{6} \mathrm{O}_{16}$ & 739.2428 & 739.2464 & ${ }^{b}\left[\left(\mathrm{M}^{14}+\mathrm{M}^{24}\right)-\mathrm{H}\right]^{-}$ & +4.8 \\
\hline & $\mathrm{C}_{46} \mathrm{H}_{56} \mathrm{~N}_{12} \mathrm{O}_{20}$ & 1095.3661 & 1095.3633 & ${ }^{b}\left[\left(2 \mathrm{M}^{14}\right)-\mathrm{H}\right]^{-}$ & -2.5 \\
\hline & $\mathrm{C}_{53} \mathrm{H}_{68} \mathrm{~N}_{12} \mathrm{O}_{26}$ & 1287.4295 & 1287.4240 & ${ }^{b}\left[\left(2 \mathrm{M}^{14}+\mathrm{M}^{24}\right)-\mathrm{H}\right]^{-}$ & -4.2 \\
\hline & $\mathrm{C}_{69} \mathrm{H}_{84} \mathrm{~N}_{18} \mathrm{O}_{30}$ & 1643.5528 & 1643.5450 & ${ }^{b}\left[\left(3 \mathrm{M}^{14}\right)-\mathrm{H}\right]^{-}$ & -4.7 \\
\hline & $\mathrm{C}_{76} \mathrm{H}_{96} \mathrm{~N}_{18} \mathrm{O}_{36}$ & 1835.6162 & 1835.6076 & ${ }^{b}\left[\left(3 \mathrm{M}^{14}+\mathrm{M}^{24}\right)-\mathrm{H}\right]^{-}$ & -4.7 \\
\hline & $\mathrm{C}_{50} \mathrm{H}_{58} \mathrm{~N}_{12} \mathrm{O}_{21}$ & 1161.3767 & 1161.3776 & ${ }^{a}\left[\left(\mathrm{M}^{11}+\mathrm{M}^{25}\right)-\mathrm{H}\right]^{-}$ & +0.8 \\
\hline & $\mathrm{C}_{27} \mathrm{H}_{34} \mathrm{~N}_{6} \mathrm{O}_{15}$ & 681.2009 & 681.1976 & ${ }^{b}\left[\left(\mathrm{M}^{14}+\mathrm{M}^{25}\right)-\mathrm{H}\right]^{-}$ & -4.9 \\
\hline & $\mathrm{C}_{46} \mathrm{H}_{56} \mathrm{~N}_{12} \mathrm{O}_{20}$ & 1095.3661 & 1095.3711 & ${ }^{b}\left[\left(2 \mathrm{M}^{14}\right)-\mathrm{H}\right]^{-}$ & +4.6 \\
\hline & $\mathrm{C}_{50} \mathrm{H}_{62} \mathrm{~N}_{12} \mathrm{O}_{25}$ & 1229.3876 & 1229.3888 & ${ }^{b}\left[\left(2 \mathrm{M}^{14}+\mathrm{M}^{25}\right)-\mathrm{H}\right]^{-}$ & +0.9 \\
\hline & $\mathrm{C}_{69} \mathrm{H}_{84} \mathrm{~N}_{18} \mathrm{O}_{30}$ & 1643.5528 & 1643.5520 & ${ }^{b}\left[\left(3 \mathrm{M}^{14}\right)-\mathrm{H}\right]^{-}$ & -0.5 \\
\hline & $\mathrm{C}_{73} \mathrm{H}_{90} \mathrm{~N}_{18} \mathrm{O}_{35}$ & 1777.5743 & 1777.5695 & ${ }^{b}\left[\left(3 \mathrm{M}^{14}+\mathrm{M}^{25}\right)-\mathrm{H}\right]^{-}$ & -2.7 \\
\hline & $\mathrm{C}_{52} \mathrm{H}_{62} \mathrm{~N}_{12} \mathrm{O}_{23}$ & 1221.3978 & 1221.3968 & ${ }^{a}\left[\left(\mathrm{M}^{11}+\mathrm{M}^{26}\right)-\mathrm{H}\right]^{-}$ & -0.8 \\
\hline & $\mathrm{C}_{29} \mathrm{H}_{38} \mathrm{~N}_{6} \mathrm{O}_{17}$ & 741.2221 & 741.2223 & ${ }^{b}\left[\left(\mathrm{M}^{14}+\mathrm{M}^{26}\right)-\mathrm{H}\right]^{-}$ & +0.3 \\
\hline & $\mathrm{C}_{46} \mathrm{H}_{56} \mathrm{~N}_{12} \mathrm{O}_{20}$ & 1095.3661 & 1095.3630 & ${ }^{b}\left[\left(2 \mathrm{M}^{14}\right)-\mathrm{H}\right]^{-}$ & -2.8 \\
\hline 26 & $\mathrm{C}_{52} \mathrm{H}_{66} \mathrm{~N}_{12} \mathrm{O}_{27}$ & 1289.4088 & 1289.4066 & ${ }^{b}\left[\left(2 \mathrm{M}^{14}+\mathrm{M}^{26}\right)-\mathrm{H}\right]^{-}$ & -1.7 \\
\hline & $\mathrm{C}_{18} \mathrm{H}_{30} \mathrm{O}_{21}$ & 581.1207 & 581.1180 & ${ }^{a}\left[\left(3 \mathrm{M}^{27}\right)-\mathrm{H}\right]^{-}$ & -4.7 \\
\hline & $\mathrm{C}_{24} \mathrm{H}_{40} \mathrm{O}_{28}$ & 775.1633 & 775.1605 & ${ }^{a}\left[\left(4 \mathrm{M}^{27}\right)-\mathrm{H}\right]^{-}$ & -3.6 \\
\hline & $\mathrm{C}_{30} \mathrm{H}_{50} \mathrm{O}_{35}$ & 969.2060 & 969.2050 & ${ }^{a}\left[\left(5 \mathrm{M}^{27}\right)-\mathrm{H}\right]^{-}$ & -1.0 \\
\hline & $\mathrm{C}_{46} \mathrm{H}_{52} \mathrm{~N}_{12} \mathrm{O}_{16}$ & 1027.3551 & 1027.3554 & ${ }^{a}\left[\left(\mathrm{M}^{11}\right)-\mathrm{H}\right]^{-}$ & +0.3 \\
\hline & $\mathrm{C}_{36} \mathrm{H}_{60} \mathrm{O}_{42}$ & 1163.2486 & 1163.2476 & ${ }^{a}\left[\left(6 \mathrm{M}^{27}\right)-\mathrm{H}\right]^{-}$ & -0.9 \\
\hline $\mathrm{OH}$ & $\mathrm{C}_{52} \mathrm{H}_{62} \mathrm{~N}_{12} \mathrm{O}_{23}$ & 1221.3978 & 1221.3939 & ${ }^{a}\left[\left(\mathrm{M}^{11}+\mathrm{M}^{27}\right)-\mathrm{H}\right]^{-}$ & -3.2 \\
\hline & $\mathrm{C}_{42} \mathrm{H}_{70} \mathrm{O}_{49}$ & 1357.2913 & 1357.2888 & ${ }^{a}\left[\left(7 \mathrm{M}^{27}\right)-\mathrm{H}\right]^{-}$ & -1.9 \\
\hline 27 & $\mathrm{C}_{58} \mathrm{H}_{72} \mathrm{~N}_{12} \mathrm{O}_{30}$ & 1415.4405 & 1415.4338 & ${ }^{a}\left[\left(\mathrm{M}^{11}+2 \mathrm{M}^{27}\right)-\mathrm{H}\right]^{-}$ & -4.7 \\
\hline & $\mathrm{C}_{29} \mathrm{H}_{38} \mathrm{~N}_{6} \mathrm{O}_{17}$ & 741.2221 & 741.2257 & ${ }^{b}\left[\left(\mathrm{M}^{14}+\mathrm{M}^{27}\right)-\mathrm{H}\right]^{-}$ & +4.9 \\
\hline & $\mathrm{C}_{46} \mathrm{H}_{56} \mathrm{~N}_{12} \mathrm{O}_{20}$ & 1095.3661 & 1095.3692 & ${ }^{b}\left[\left(2 \mathrm{M}^{14}\right)-\mathrm{H}\right]^{-}$ & +2.8 \\
\hline & $\mathrm{C}_{52} \mathrm{H}_{66} \mathrm{~N}_{12} \mathrm{O}_{27}$ & 1289.4088 & 1289.4030 & ${ }^{b}\left[\left(2 \mathrm{M}^{14}+\mathrm{M}^{27}\right)-\mathrm{H}\right]^{-}$ & -4.5 \\
\hline
\end{tabular}

${ }^{a} \mathrm{Ht} / \mathrm{Gt} \mathrm{11/22-27},{ }^{b} \mathrm{Ht} / \mathrm{Gt}$ 14/22-27. 

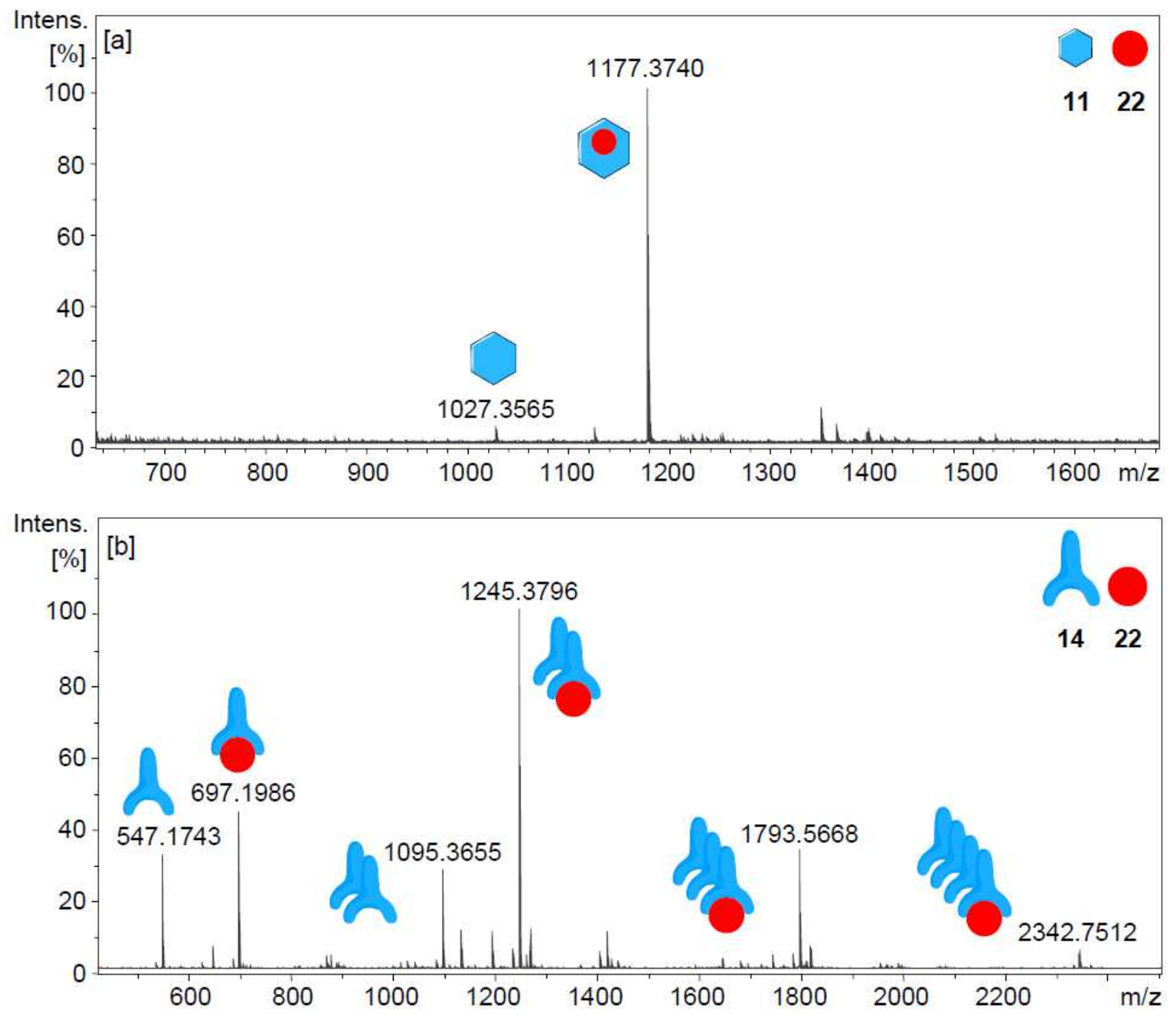

Figure 5. ESI-TOF MS of Ht/Gt complexes $(a)$ 11/22 and (b) 14/22 in the negative ion mode.

\section{Molecular modeling studies}

The molecular recognition studies by ESI-TOF MS and ESI-MS/MS were complemented by molecular modeling optimizations in order to explore the proper sites of the $\mathrm{Ht} / \mathrm{Ht}$ and $\mathrm{Ht} / \mathrm{Gt}$ interactions. The molecular structures of compounds $\mathbf{9}$ and $\mathbf{1 8}$ were energy minimized at the AM1 level using HyperChem software (Release 8.0) until the root mean square (RMS) gradient was less than or equal to $0.01 \mathrm{kcal}^{\mathrm{mol}} \mathrm{m}^{-1} \cdot{ }^{35,36}$ The through space interactions from the 2D ROESY NMR experiments were used for subsequent structure model building. The computed structure of macrocycle 9 indicated the presence of four $\mathrm{CONH}$ moieties in the cis conformation, which is essential for the success of macrocyclization reaction. A syn/anti orientation of the $\mathrm{NH}$ moieties would give undesired polymers. It also showed free rotation around $\mathrm{C}^{(16)}-\mathrm{C}^{(17)}$ and 
$\mathrm{C}^{(36)}-\mathrm{C}^{(37)}$ single bonds (Figure 6). The molecular electrostatic potential (MEP) modeling was used to predict the possible sites of recognition between the $\mathrm{Ht} / \mathrm{Ht}$ and $\mathrm{Ht} / \mathrm{Gt}$ aggregates. The MEP maps of compounds $\mathbf{9}$ and $\mathbf{1 8}$ showed that the negative potential sites are located on the dioxolane and carbonyl oxygen atoms, while the positive potential sites are around the $\mathrm{NH}$ hydrogen atoms. The computed structure of the Ht/Gt complex 9/22 showed possibility of formation of an intermolecular $\mathrm{H}$-bond between $\mathrm{CO}^{(5) \cdots} \mathrm{COOH}$, while that of the $\mathrm{Ht} / \mathrm{Gt}$ complex $\mathbf{1 8} / \mathbf{2 2}$ showed formation of two intramolecular $\mathrm{H}$-bonds between $\mathrm{CO}^{\left(5^{\prime}\right) \cdots} \mathrm{N} H^{(3)}$ and $\mathrm{CO}^{(5) \cdots} \mathrm{N} H^{\left(3^{\prime}\right)}$. It also showed formation of an intermolecular $\mathrm{H}$-bond between $\mathrm{CO}^{(5) \cdots} \mathrm{COOH}$. The $\mathrm{Ht} / \mathrm{Ht}$ assembly takes place through formation of two intermolecular $\mathrm{H}$-bonds between $\mathrm{CO}^{\left(5^{\prime}\right) \cdots} \mathrm{N} H^{(4)}$ and $\mathrm{CO}^{(5) \cdots} \mathrm{NH}^{\left(4^{\prime}\right)}$.

[a]
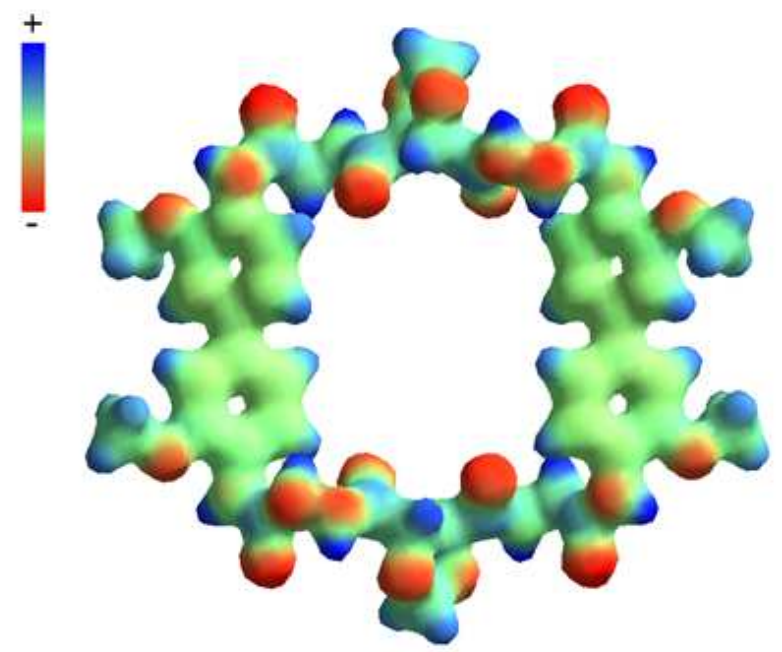

[b]

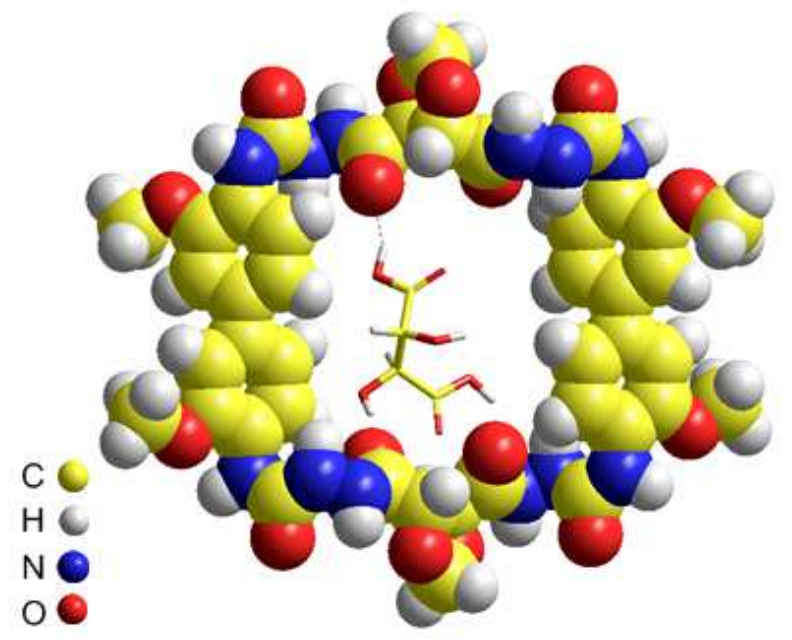

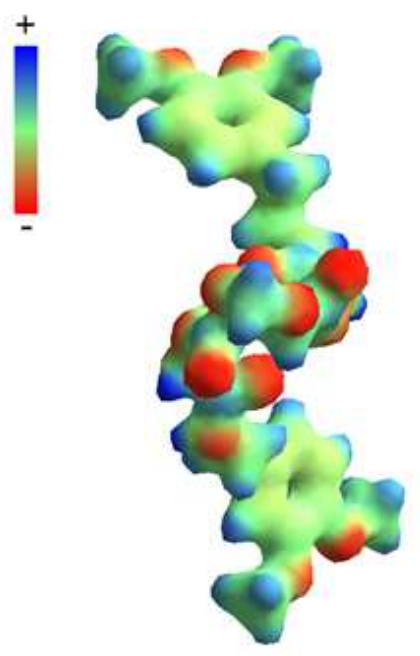

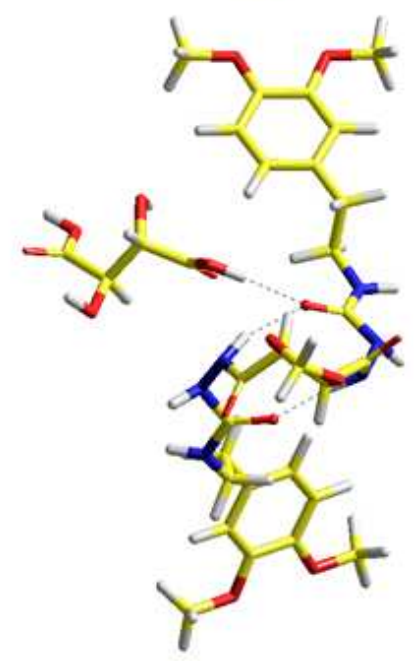

Figure 6. (a) Molecular electrostatic potentials of compounds 9 and 18. (b) Energy minimized structures of Ht/Gt complexes 9/22 and 18/22. 


\section{Conclusions}

In summary, we have synthesized new tetra-(hydrazinecarboxamide) cyclophanes with unexpected antilanti conformation and their open-framework analogous. The molecular recognition of the new compounds to a selection of chiral carboxylic guests was investigated by using ESI-TOF MS and ESI-MS/MS. The conformation of the macrocycles obtained by addition of the dioxolane dihydrazides to the aromatic diisocyanate is largely dependent on the geometry of the diisocyanate precursors. On reaction with the dioxolane dicarbohydrazides, diisocyanates with dihedral angles less than $180^{\circ}$ give cyclophanes with a syn/anti conformation, while diisocyanates with dihedral angles equal $180^{\circ}$ form cyclophanes with an anti/anti conformation. The ESITOF MS and ESI-MS/MS investigation of the molecular recognition of the cyclophane macrocycles to the chiral carboxylic guests confirmed formation of stable $1: 1 \mathrm{Ht} / \mathrm{Gt}$ complexes. The open-framework compounds formed structurally unique supramolecular row-like aggregates with the carboxylic guests in the order $[(n \mathrm{Ht}+\mathrm{Gt})-\mathrm{H}]^{-}(n=1-4)$.

\section{Experimental Section}

General. All solvents and reagents used for the reactions were purchased from Sigma-Aldrich (Munich, Germany) or Applichem (Darmstadt, Germany) and were used as obtained without further purification. Whenever possible the reactions were monitored by thin layer chromatography (TLC). TLC was performed on Macherey-Nagel aluminium-backed plates pre-coated with silica gel $60\left(\mathrm{UV}_{254}\right)$ (Macherey-Nagel, Düren, Germany). Melting points were determined in open capillaries using a Buechl B-545 melting point apparatus and are not corrected. Infrared spectra were determined using a Vector-33 Bruker FT-IR spectrometer. The samples were measured directly as solids or oils; $v_{\max }$ values were expressed in $\mathrm{cm}^{-1}$ and were given for the main absorption bands. The ${ }^{1} \mathrm{H}$ NMR, ${ }^{13} \mathrm{C}$ NMR, HMBC, HMQC and ROESY NMR spectra were acquired on a JEOL ECX-400 spectrometer. The NMR instrument was operated at $400 \mathrm{MHz}$ for ${ }^{1} \mathrm{H}$ NMR and $100 \mathrm{MHz}$ for ${ }^{13} \mathrm{C} \mathrm{NMR}$ in DMSO- $d_{6}$ using a $5 \mathrm{~mm}$ probe. The chemical shifts $(\delta)$ were reported in parts per million (ppm) and referenced to the residual solvent peak. The following abbreviations are used: s, singlet; m, multiplet; br, broad signal. The ESI-TOF MS data were acquired on a high resolution micrOTOF Focus mass spectrometer (exceeding 15000 FWHM) in the negative or positive ion modes (Bruker Daltonics, Bremen, Germany) and the samples were dissolved in DMF, $\mathrm{CH}_{3} \mathrm{CN}$ and $\mathrm{H}_{2} \mathrm{O}$. The analytical solutions were directly injected into the mass spectrometer via a syringe pump at a flow rate of $180 \mu \mathrm{L} / \mathrm{h}$. Calibration was carried out using a $0.1 \mathrm{M}$ solution of sodium formate in the enhanced quadratic mode prior to each experimental run. The ESI-MS/MS experiments were performed in an ion trap HCTultra Bruker Daltonics mass spectrometer and the results were collected and analyzed with Compass 1.3 data analysis software for a Bruker Daltonics mass spectrometer. Molecular modeling calculations were performed using HyperChem software (Release 8.0) at the AM1 level and no influence of 
solvents was taken into account. Circular dichroism measurements were carried out using JascoJ-810 spectropolarimeter in DMSO. Dioxolane dicarbohydrazides 1-5 were prepared according to the literature. ${ }^{24,25,39}$

$(6 R, 7 R, 26 R, 27 R)$-Tetra-(hydrazinecarboxamide) cyclophane 9. To a stirred solution of 4,4'diisocyanato-3,3'-dimethoxy-1,1'-biphenyl 6 (588.2 $\mathrm{mg}, 1.69 \mathrm{mmol})$ in anhydrous THF (5 mL) was added (4R,5R)-1,3-dioxolane-4,5-dicarbohydrazide 1 (340 $\mathrm{mg}, 1.79 \mathrm{mmol})$ in $4 \mathrm{~mL}$ anhydrous THF. The mixture was stirred at room temperature for $24 \mathrm{~h}$. The pale yellow precipitate was filtered, washed successively with $\mathrm{H}_{2} \mathrm{O}, \mathrm{Et}_{2} \mathrm{O}$ and dried to give the title compound 9 ( $820 \mathrm{mg}$, 94\%). Mp > $230{ }^{\circ} \mathrm{C}$ (decomp.). FT-IR $v_{\max } / \mathrm{cm}^{-1} 3238$ (NH), 1674 (CO). ${ }^{1} \mathrm{H}$ NMR (400 MHz, DMSO- $\left.d_{6}\right) \delta_{\mathrm{H}} / \mathrm{ppm} 10.1$ (brs, 4H, NH), 8.7 (brs, 4H, NH), 8.1 (brs, 4H, NH), 8 (m, 4H, ArH), 7.2 (s, 4H, ArH), 7.1 (m, 4H, ArH), 5.1 (brs, 4H, CH $H_{2}, 4.6$ (brs, $\left.4 \mathrm{H}, \mathrm{CH}\right), 3.9\left(\mathrm{~s}, 12 \mathrm{H}, \mathrm{OCH}_{3}\right) .{ }^{13} \mathrm{C}$ NMR $\left(100 \mathrm{MHz}, \mathrm{DMSO}-d_{6}\right) \delta_{\mathrm{C}} / \mathrm{ppm} 169.1,155.1,148.4,134.5,127.9,119,118.7,109.4,97.1$, 77.2, 56.5. HRMS (ESI-TOF MS, +MS) $m / z$ (Calcd. 973.3071 found 973.3059, $[\mathrm{M}+\mathrm{H}]^{+}$).

$(6 R, 7 R, 26 R, 27 R)$-Tetra-(hydrazinecarboxamide) cyclophane 10 . To a stirred solution of 4,4'diisocyanato-3,3'-dimethoxy-1,1'-biphenyl 6 (588.2 $\mathrm{mg}, 1.69 \mathrm{mmol})$ in anhydrous THF (5 mL) was added (2R,3R)-1,4-dioxaspiro[4.5]decane-2,3-dicarbohydrazide 2 (462 $\mathrm{mg}, 1.79 \mathrm{mmol})$ in 4 $\mathrm{mL}$ anhydrous THF. The mixture was stirred at room temperature for $24 \mathrm{~h}$. The pale yellow precipitate was filtered, washed successively with $\mathrm{H}_{2} \mathrm{O}, \mathrm{Et}_{2} \mathrm{O}$ and dried to give the title compound 10 (830 mg, 88\%). Mp > $230{ }^{\circ} \mathrm{C}$ (decomp.). FT-IR $v_{\max } / \mathrm{cm}^{-1} 3290(\mathrm{~N} H), 1682$ (CO). ${ }^{1} \mathrm{H}$ NMR (400 MHz, DMSO- $d_{6}$ ) $\delta_{\mathrm{H}} / \mathrm{ppm} 10$ (brs, 4H, NH), 8.7 (brs, 4H, NH), 8.1 (brs, 4H, NH), $8(\mathrm{~d}, J=8.2,4 \mathrm{H}, \operatorname{Ar} H), 7.2(\mathrm{~s}, 4 \mathrm{H}, \operatorname{Ar} H), 7.1(\mathrm{~d}, J=8.2,4 \mathrm{H}, \mathrm{ArH}), 4.6$ (brs, 4H, CH), 3.9 (s, $\left.12 \mathrm{H}, \mathrm{OCH}_{3}\right), 1.7-1.5\left(\mathrm{~m}, 16 \mathrm{H}, \mathrm{CH}_{2}\right), 1.3$ (brs, 4H, $\left.\mathrm{CH}_{2}\right) .{ }^{13} \mathrm{C}$ NMR (100 MHz, DMSO-d $\left.{ }_{6}\right)$ $\delta_{\mathrm{C}}$ ppm 169.3, 155.1, 148.4, 134.5, 127.9, 119, 118.8, 113.8, 109.4, 76.8, 56.5, 35.7, 25, 23.9. HRMS (ESI-TOF MS, +MS) $\mathrm{m} / \mathrm{z}$ (Calcd. 1109.4323 found $1109.4335,[\mathrm{M}+\mathrm{H}]^{+}$).

$(6 R, 7 R, 26 R, 27 R)$-Tetra-(hydrazinecarboxamide) cyclophane 11 . To a stirred solution of 4,4'diisocyanato-3,3'-dimethoxy-1,1'-biphenyl $6(500 \mathrm{mg}, 1.68 \mathrm{mmol})$ in anhydrous THF (4 mL) was added (4R,5R)-2,2-dimethyl-1,3-dioxolane-4,5-dicarbohydrazide 3 (390 mg, $1.78 \mathrm{mmol}$ ) in $4 \mathrm{~mL}$ anhydrous THF. The mixture was stirred at room temperature for $24 \mathrm{~h}$. The pale yellow precipitate was filtered, washed successively with $\mathrm{H}_{2} \mathrm{O}, \mathrm{Et}_{2} \mathrm{O}$ and dried to give the title compound 11 (680 mg, 78\%). Mp > $235{ }^{\circ} \mathrm{C}$ (decomp.). FT-IR $v_{\max } / \mathrm{cm}^{-1} 3276(\mathrm{NH}), 1681$ (CO). ${ }^{1} \mathrm{H}$ NMR (400 MHz, DMSO- $d_{6}$ ) $\delta_{\mathrm{H}} / \mathrm{ppm} 10$ (brs, 4H, NH), 8.7 (brs, 4H, NH), 8.1 (brs, 4H, NH), $8(\mathrm{~d}, J=8.2,4 \mathrm{H}, \operatorname{Ar} H), 7.2(\mathrm{~s}, 4 \mathrm{H}, \operatorname{Ar} H), 7.1$ (d, $J=8.2,4 \mathrm{H}, \operatorname{ArH}), 4.6$ (brs, 4H, CH), 3.9 (s, $\left.12 \mathrm{H}, \mathrm{OCH}_{3}\right), 1.4\left(\mathrm{~s}, 12 \mathrm{H}, \mathrm{CH}_{3}\right) .{ }^{13} \mathrm{C}$ NMR $\left(100 \mathrm{MHz}, \mathrm{DMSO}-d_{6}\right) \delta_{\mathrm{C}} / \mathrm{ppm} 169.2,155.1,148.4$, 134.5, 128, 119, 118.8, 113.2, 109.4, 77.1, 56.4, 26.7. HRMS (ESI-TOF MS, +MS) $\mathrm{m} / z$ (Calcd. 1051.3516 found $\left.1051.3541,[\mathrm{M}+\mathrm{Na}]^{+}\right)$.

$(6 S, 7 S, 26 S, 27 S)$-Tetra-(hydrazinecarboxamide) cyclophane 12. To a stirred solution of 4,4'diisocyanato-3,3'-dimethoxy-1,1'-biphenyl $6(588.2 \mathrm{mg}, 1.69 \mathrm{mmol})$ in anhydrous THF (5 mL) was added (4S,5S)-1,3-dioxolane-4,5-dicarbohydrazide 4 (340 $\mathrm{mg}, 1.79 \mathrm{mmol})$ in $4 \mathrm{~mL}$ anhydrous THF. The mixture was stirred at room temperature for $24 \mathrm{~h}$. The pale yellow precipitate was filtered, washed successively with $\mathrm{H}_{2} \mathrm{O}, \mathrm{Et}_{2} \mathrm{O}$ and dried to give the title compound $\mathbf{1 2}$ (790 mg, 
90\%). $\mathrm{Mp}>225{ }^{\circ} \mathrm{C}$ (decomp.). FT-IR $v_{\max } / \mathrm{cm}^{-1} 3256$ (NH), 1668 (CO). ${ }^{1} \mathrm{H}$ NMR (400 MHz, DMSO- $\left.d_{6}\right) \delta_{\mathrm{H}} / \mathrm{ppm} 10.1$ (brs, 4H, NH), 8.7 (brs, 4H, NH), 8.1 (brs, 4H, NH), 8 (m, 4H, ArH), 7.2 (s, 4H, ArH), 7.1 (m, 4H, ArH), 5.1 (brs, 4H, CH $), 4.6$ (brs, $4 \mathrm{H}, \mathrm{CH}), 3.9$ (s, $\left.12 \mathrm{H}, \mathrm{OCH}_{3}\right) .{ }^{13} \mathrm{C}$ NMR $\left(100 \mathrm{MHz}, \mathrm{DMSO}-d_{6}\right) \delta_{\mathrm{C}} / \mathrm{ppm} 169.1,155.1,148.4,134.5,127.9,119,118.7,109.4,97.1$, 77.2, 56.5. HRMS (ESI-TOF MS, +MS) $\mathrm{m} / z$ (Calcd. 973.2925 found 973.2945, $[\mathrm{M}+\mathrm{H}]^{+}$).

$(6 S, 7 S, 26 S, 27 S)$-Tetra-(hydrazinecarboxamide) cyclophane 13. To a stirred solution of 4,4'diisocyanato-3,3'-dimethoxy-1,1'-biphenyl 6 (500 mg, $1.68 \mathrm{mmol})$ in anhydrous THF (4 mL) was added (4S,5S)-2,2-dimethyl-1,3-dioxolane-4,5-dicarbohydrazide 5 (390 mg, $1.78 \mathrm{mmol}$ ) in 4 $\mathrm{mL}$ anhydrous THF. The mixture was stirred at room temperature for $24 \mathrm{~h}$. The pale yellow precipitate was filtered, washed successively $\mathrm{H}_{2} \mathrm{O}, \mathrm{Et}_{2} \mathrm{O}$ and dried to give the title compound $\mathbf{1 3}$ (660 mg, 76\%). Mp > $225{ }^{\circ} \mathrm{C}$ (decomp.). FT-IR $v_{\max } / \mathrm{cm}^{-1} 3295(\mathrm{NH}), 1681(\mathrm{CO}) .{ }^{1} \mathrm{H}$ NMR (400 MHz, DMSO- $\left.d_{6}\right) \delta_{\mathrm{H}} / \mathrm{ppm} 10$ (brs, 4H, NH), 8.7 (brs, 4H, NH), 8.1 (brs, 4H, NH), 8 (d, $J=8.2$, 4H, $\mathrm{ArH}$ ), 7.2 (s, 4H, $\mathrm{ArH}$ ), 7.1 (d, $J=8.2,4 \mathrm{H}, \mathrm{ArH}$ ), 4.6 (brs, 4H, CH), 3.9 (s, 12H, $\mathrm{OCH}_{3}$ ), 1.4 $\left(\mathrm{s}, 12 \mathrm{H}, \mathrm{CH}_{3}\right) .{ }^{13} \mathrm{C}$ NMR $\left(100 \mathrm{MHz}, \mathrm{DMSO}-d_{6}\right) \delta_{\mathrm{C}} / \mathrm{ppm} 169.2,155.1,148.4,134.5,127.9,119$, 118.8, 113.2, 109.4, 77.1, 56.4, 26.7. HRMS (ESI-TOF MS, -MS) $m / z$ (Calcd. 1027.3551 found 1027.3588, [M-H] $\left.]^{-}\right)$.

2,2'-((4R,5R)-1,3-Dioxolane-4,5-dicarbonyl)bis[ $N$-(3,5-dimethoxyphenyl)hydrazinecarboxamide] 14. To a stirred solution of 3,5-dimethoxyphenyl isocyanate $(500 \mathrm{mg}, 2.79 \mathrm{mmol})$ in anhydrous THF (6 mL) was added (4R,5R)-1,3-dioxolane-4,5-dicarbohydrazide 1 (285 mg, $1.5 \mathrm{mmol})$ in $6 \mathrm{~mL}$ anhydrous THF. The mixture was stirred at room temperature for $24 \mathrm{~h}$. The white precipitate was filtered, washed successively with $\mathrm{H}_{2} \mathrm{O}, \mathrm{Et}_{2} \mathrm{O}$ and dried to give the title compound 14 (670 mg, 87\%). Mp > $200{ }^{\circ} \mathrm{C}$ (decomp.). FT-IR $v_{\max } / \mathrm{cm}^{-1} 3326$ (NH), 1655 (CO). ${ }^{1} \mathrm{H}$ NMR (400 $\left.\mathrm{MHz}, \mathrm{DMSO}-d_{6}\right) \delta_{\mathrm{H}} / \mathrm{ppm} 10$ (brs, 2H, NH), 8.7 (brs, 2H, NH), 8.1 (brs, 2H, NH), 6.6 (m, 4H, $\mathrm{ArH}), 6$ (m, 2H, $\mathrm{ArH}), 5.1$ (brs, 2H, $\left.\mathrm{CH}_{2}\right), 4.6$ (brs, $\left.2 \mathrm{H}, \mathrm{CH}\right), 3.6$ (s, 12H, OCH 3$) .{ }^{13} \mathrm{C} \mathrm{NMR}(100$ MHz, DMSO- $\left.d_{6}\right) \delta_{\mathrm{C}}$ ppm 169.3, 161, 155.2, 141.8, 97.2, 97, 94.5, 77.2, 55.5. HRMS (ESI-TOF MS, -MS) $m / z$ (Calcd. 547.1794 found 547.1816, [M-H] ${ }^{\top}$ ).

\section{2,2'-((4R,5R)-1,3-Dioxolane-4,5-dicarbonyl)bis[ $N$-(4-phenoxyphenyl)hydrazinecarboxamide]}

15. To a stirred solution of 4-phenoxyphenyl isocyanate $(0.5 \mathrm{~mL}, 2.77 \mathrm{mmol})$ in anhydrous THF $(6 \mathrm{~mL})$ was added $(4 R, 5 R)$-1,3-dioxolane-4,5-dicarbohydrazide $1(283 \mathrm{mg}, 1.48 \mathrm{mmol})$ in $6 \mathrm{~mL}$ anhydrous THF. The mixture was stirred at room temperature for $24 \mathrm{~h}$. The white precipitate was filtered, washed successively with $\mathrm{H}_{2} \mathrm{O}, \mathrm{Et}_{2} \mathrm{O}$ and dried to give the title compound $\mathbf{1 5}$ (840 mg, 99\%). Mp 218-219 ${ }^{\circ} \mathrm{C}$. FT-IR $v_{\max } / \mathrm{cm}^{-1} 3270$ (NH), 1690 (CO). ${ }^{1} \mathrm{H}$ NMR (400 MHz, DMSO- $d_{6}$ ) $\delta_{\mathrm{H}} / \mathrm{ppm} 10$ (brs, 2H, NH), 8.7 (brs, 2H, NH), 8.1 (brs, 2H, NH), 7.41-7.45 (m, 4H, ArH), 7.2-7.3 (m, 4H, ArH), 7.02-7.05 (m, 2H, ArH), 6.8-6.9 (m, 8H, ArH), 5.1 (brs, 2H, CH ( $_{2}$ ) 4.6 (brs, 2H, $\mathrm{CH}) .{ }^{13} \mathrm{C}$ NMR $\left(100 \mathrm{MHz}, \mathrm{DMSO}-d_{6}\right) \delta_{\mathrm{C}} / \mathrm{ppm} 169.3,158.1,155.6,151.2,136,130.4,123.2$, 120.8, 120.1, 118.1, 97, 77.2. HRMS (ESI-TOF MS, -MS) m/z (Calcd. 611.1896 found 611.1920, [M-H] $)$.

2,2'-((4R,5R)-1,3-Dioxolane-4,5-dicarbonyl)bis[ $N$-(4-methoxybenzyl)hydrazinecarboxamide] 16. To a stirred solution of 1-(isocyanatomethyl)-4-methoxybenzene $(0.5 \mathrm{~mL}, 3.50 \mathrm{mmol})$ in anhydrous THF (6 mL) was added $(4 R, 5 R)$-1,3-dioxolane-4,5-dicarbohydrazide 1 (352.08 mg, 
$1.85 \mathrm{mmol}$ ) in $6 \mathrm{~mL}$ anhydrous THF. The mixture was stirred at room temperature for $24 \mathrm{~h}$. The white precipitate was filtered, washed successively with $\mathrm{H}_{2} \mathrm{O}, \mathrm{Et}_{2} \mathrm{O}$ and dried to give the title compound 16 (740 mg, 81\%). Mp > $200{ }^{\circ} \mathrm{C}$. FT-IR $v_{\max } / \mathrm{cm}^{-1}(\mathrm{NH}), 1681(\mathrm{CO}) .{ }^{1} \mathrm{H}$ NMR (400 MHz, DMSO-d $\left.d_{6}\right) \delta_{\mathrm{H}} / \mathrm{ppm} 9.9$ (brs, 2H, NH), 7.8 (brs, 2H, NH), $7.1(\mathrm{~m}, 4 \mathrm{H}, \operatorname{Ar} H), 6.8(\mathrm{~m}, 6 \mathrm{H}$, $\mathrm{ArH}$ and $\mathrm{NH}$ ), 5.1 (brs, 2H, $\left.\mathrm{CH}_{2}\right), 4.6$ (brs, $\left.2 \mathrm{H}, \mathrm{CH}\right), 4.1\left(\mathrm{~m}, 4 \mathrm{H}, \mathrm{CH}_{2}\right), 3.6\left(\mathrm{~s}, 6 \mathrm{H}, \mathrm{OCH}_{3}\right) .{ }^{13} \mathrm{C}$ NMR $\left(100 \mathrm{MHz}, \mathrm{DMSO}-d_{6}\right) \delta_{\mathrm{C}} / \mathrm{ppm} 169.3,158.6,158.2,132.8,128.8,114,96.8,77.2,55.5$, 42.6. HRMS (ESI-TOF MS, -MS) $m / z$ (Calcd. 515.1896 found 515.1878, [M-H] ${ }^{-}$).

2,2'-((4R,5R)-1,3-Dioxolane-4,5-dicarbonyl)bis( $N$-(4-benzylphenyl)hydrazinecarboxamide)

17. To a stirred solution of 4-benzylphenyl isocyanate $(0.5 \mathrm{~mL}, 2.65 \mathrm{mmol})$ in anhydrous THF (6 $\mathrm{mL})$ was added (4R,5R)-1,3-dioxolane-4,5-dicarbohydrazide $1(271.3 \mathrm{mg}, 1.42 \mathrm{mmol})$ in $6 \mathrm{~mL}$ anhydrous THF. The mixture was stirred at room temperature for $24 \mathrm{~h}$. The white precipitate was filtered, washed successively with $\mathrm{H}_{2} \mathrm{O}, \mathrm{Et}_{2} \mathrm{O}$ and dried to give the title compound 17 (800 mg, 99\%). Mp 233-234 ${ }^{\circ} \mathrm{C}$. FT-IR $v_{\max } / \mathrm{cm}^{-1} 3269(\mathrm{NH}), 1688$ (CO) $\mathrm{cm}^{-1}$. ${ }^{1} \mathrm{H}$ NMR (400 MHz, DMSO- $\left.d_{6}\right) \delta_{\mathrm{H}} / \mathrm{ppm} 10$ (brs, 2H, NH), 8.6 (brs, 2H, NH), 8.1 (brs, 2H, NH), 7.3 (m, 4H, ArH), 7.20-7.25 (m, 4H, $\mathrm{ArH}$ ), 7.13-7.17 (m, 6H, $\mathrm{ArH}), 7$ (m, 4H, ArH), 5.1 (brs, 2H, $\mathrm{CH}_{2}$ ), 4.6 (brs, $2 \mathrm{H}, \mathrm{CH}$ ), 3.8 (brs, $\left.4 \mathrm{H}, \mathrm{CH}_{2}\right) .{ }^{13} \mathrm{C}$ NMR (100 MHz, DMSO- $\left.d_{6}\right) \delta_{\mathrm{C}} / \mathrm{ppm} 169.3,155.5,142.1,138$, 135.3, 129.4, (129.1, 128.9), 126.3, 119.2, 97, 77.2, 41. HRMS (ESI-TOF MS, -MS) $\mathrm{m} / \mathrm{z}$ (Calcd. 607.2311 found 607.2308, [M-H] $\left.{ }^{\top}\right)$.

2,2'-((4R,5R)-1,3-Dioxolane-4,5-dicarbonyl)bis( $N$-(3,4-dimethoxyphenethyl)hydrazinecarboxamide) 18. To a stirred solution of 4-(2-isocyanatoethyl)-1,2-dimethoxybenzene ( $0.5 \mathrm{~mL}, 2.74$ $\mathrm{mmol})$ in anhydrous THF (6 mL) was added (4R,5R)-1,3-dioxolane-4,5-dicarbohydrazide 1 (280 $\mathrm{mg}, 1.47 \mathrm{mmol}$ ) in $6 \mathrm{~mL}$ anhydrous THF. The mixture was stirred at room temperature for $24 \mathrm{~h}$. The white precipitate was filtered, washed successively with $\mathrm{H}_{2} \mathrm{O}, \mathrm{Et}_{2} \mathrm{O}$ and dried to give the title compound $18(710 \mathrm{mg}, 85 \%) . \mathrm{Mp}>115-116{ }^{\circ} \mathrm{C}$. FT-IR $v_{\max } / \mathrm{cm}^{-1} 3324(\mathrm{NH}), 1667(\mathrm{CO}) .{ }^{1} \mathrm{H}$ NMR (400 MHz, DMSO- $d_{6}$ ) $\delta_{\mathrm{H}} / \mathrm{ppm} 9.8$ (brs, 2H, NH), 7.8 (brs, 2H, NH), 6.8 (m, 2H, ArH), 6.7 (m, 2H, ArH), 6.65-6.68 (m, 2H, ArH), 6.3 (m, 2H, NH), 5 (brs, 2H, $\mathrm{CH}_{2}$ ), 4.5 (brs, 2H, CH), 3.7 $\left(\mathrm{s}, 6 \mathrm{H}, \mathrm{OCH}_{2}\right), 3.6\left(\mathrm{~s}, 6 \mathrm{H}, \mathrm{OCH}_{3}\right), 3.1-3.2\left(\mathrm{~m}, 4 \mathrm{H}, \mathrm{CH}_{2}\right), 2.5\left(\mathrm{t}, J=7.3,4 \mathrm{H}, \mathrm{CH}_{2}\right) .{ }^{13} \mathrm{C} \mathrm{NMR}(100$ MHz, DMSO- $\left.d_{6}\right) \delta_{\mathrm{C}}$ ppm 169.1, 158.1, 149.1, 147.7, 132.4, 120.9, 113, 112.4, 96.9, 77.2, 56, 55.8, 41.6, 35.9. HRMS (ESI-TOF MS, -MS) $\mathrm{m} / \mathrm{z}$ (Calcd. 603.2420 found 603.2419, [M-H] ${ }^{-}$).

2,2'-((4S,5S)-1,3-Dioxolane-4,5-dicarbonyl)bis( $N$-(3,5-dimethoxyphenyl)hydrazinecarboxa-

mide) 19. To a stirred solution of 3,5-dimethoxyphenyl isocyanate $(500 \mathrm{mg}, 2.79 \mathrm{mmol})$ in anhydrous THF (6 mL) was added (4S,5S)-1,3-dioxolane-4,5-dicarbohydrazide 4 (285 mg, $1.5 \mathrm{mmol})$ in $6 \mathrm{~mL}$ anhydrous THF. The mixture was stirred at room temperature for $24 \mathrm{~h}$. The white precipitate was filtered, washed successively with $\mathrm{H}_{2} \mathrm{O}, \mathrm{Et}_{2} \mathrm{O}$ and dried to give the title compound 19 (550 mg, 71\%). Mp > $200{ }^{\circ} \mathrm{C}$. FT-IR $v_{\max } / \mathrm{cm}^{-1} 3323$ (NH), 1657 (CO). ${ }^{1} \mathrm{H}$ NMR (400 MHz, DMSO- $\left.d_{6}\right) \delta_{\mathrm{H}} / \mathrm{ppm} 10$ (brs, 2H, NH), 8.7 (brs, 2H, NH), 8.1 (brs, 2H, NH), 6.6 (m, 4H, ArH), 6 (m, 2H, ArH), 5.1 (brs, 2H, $\left.\mathrm{CH}_{2}\right), 4.6$ (brs, $\left.2 \mathrm{H}, \mathrm{CH}\right), 3.6\left(\mathrm{~s}, 12 \mathrm{H}, \mathrm{OCH}_{3}\right) .{ }^{13} \mathrm{C} \mathrm{NMR}(100 \mathrm{MHz}$, DMSO- $\left.d_{6}\right) \delta_{\mathrm{C}} / \mathrm{ppm} 169.3,161,155.2,141.7,97.2$, 97, 94.5, 77.2, 55.5. HRMS (ESI-TOF MS, -MS) $\mathrm{m} / z$ (Calcd. 547.1794 found 547.1784, [M-H] $\left.{ }^{-}\right)$. 
2,2'-((4S,5S)-1,3-dioxolane-4,5-dicarbonyl)bis( $N$-(4-phenoxyphenyl)hydrazinecarboxamide) 20. To a stirred solution of 4-phenoxyphenyl isocyanate $(0.3 \mathrm{~mL}, 1.66 \mathrm{mmol})$ in anhydrous THF $(6 \mathrm{~mL})$ was added $(4 S, 5 S)$-1,3-dioxolane-4,5-dicarbohydrazide $4(177 \mathrm{mg}, 0.93 \mathrm{mmol})$ in $6 \mathrm{~mL}$ anhydrous THF. The mixture was stirred at room temperature for $24 \mathrm{~h}$. The white precipitate was filtered, washed successively with $\mathrm{H}_{2} \mathrm{O}, \mathrm{Et}_{2} \mathrm{O}$ and dried to give the title compound $\mathbf{2 0}$ (450 mg, $88 \%$ ). Mp 217-218 ${ }^{\circ} \mathrm{C}$. FT-IR $v_{\max } / \mathrm{cm}^{-1} 3274$ (NH), 1690 (CO). ${ }^{1} \mathrm{H}$ NMR (400 MHz, DMSO- $d_{6}$ ) $\delta_{\mathrm{H}} / \mathrm{ppm} 10$ (brs, 2H, NH), 8.7 (brs, 2H, NH), 8.1 (brs, 2H, NH), 7.42-7.44 (m, 4H, ArH), 7.2-7.3 (m, 4H, ArH), 7.01-7.05 (m, 2H, ArH), 6.8-6.9 (m, 8H, ArH), 5.1 (brs, 2H, CH CH $_{2} 4.6$ (brs, 2H, $\mathrm{CH}) .{ }^{13} \mathrm{C}$ NMR $\left(100 \mathrm{MHz}, \mathrm{DMSO}-d_{6}\right) \delta_{\mathrm{C}} / \mathrm{ppm} 169.3,158.1,155.6,151.2,136,130.4,123.2$, 120.8, 120.1, 118.1, 97, 77.2. HRMS (ESI-TOF MS, -MS) m/z (Calcd. 611.1896 found $\left.611.1873,[\mathrm{M}-\mathrm{H}]^{-}\right)$.

2,2'-((4S,5S)-1,3-dioxolane-4,5-dicarbonyl)bis( $N$-(4-methoxybenzyl)hydrazinecarboxamide) 21. To a stirred solution of 1-(isocyanatomethyl)-4-methoxybenzene $(0.15 \mathrm{~mL}, 3.50 \mathrm{mmol})$ in anhydrous THF (6 mL) was added $(4 S, 5 S)$-1,3-dioxolane-4,5-dicarbohydrazide 4 (119 mg, 0.63 $\mathrm{mmol}$ ) in $6 \mathrm{~mL}$ anhydrous THF. The mixture was stirred at room temperature for $24 \mathrm{~h}$. The white precipitate was filtered, washed successively with $\mathrm{H}_{2} \mathrm{O}, \mathrm{Et}_{2} \mathrm{O}$ and dried to give the title compound $21(200 \mathrm{mg}, 73 \%)$. Mp > 210-211 ${ }^{\circ} \mathrm{C}$. FT-IR $v_{\max } / \mathrm{cm}^{-1}$ (NH), 1683 (CO). ${ }^{1} \mathrm{H}$ NMR (400 MHz, DMSO- $d_{6}$ ) $\delta_{\mathrm{H}} / \mathrm{ppm} 9.9$ (brs, 2H, NH), 7.8 (brs, 2H, NH), 7.1 (m, 4H, ArH), 6.80-6.84 (m, 6H, $\mathrm{ArH}$ and $\mathrm{NH}), 5$ (brs, 2H, $\left.\mathrm{CH}_{2}\right), 4.6$ (brs, $\left.2 \mathrm{H}, \mathrm{CH}\right), 4.10-4.13\left(\mathrm{~m}, 4 \mathrm{H}, \mathrm{CH}_{2}\right), 3.6(\mathrm{~s}, 6 \mathrm{H}$, $\left.\mathrm{OCH}_{3}\right) .{ }^{13} \mathrm{C}$ NMR $\left(100 \mathrm{MHz}, \mathrm{DMSO}-d_{6}\right) \delta_{\mathrm{C}} \mathrm{ppm} 169.3,158.6,158.3,132.8,128.8,114,96.8$, 77.2, 55.5, 42.6. HRMS (ESI-TOF MS, -MS) m/z (Calcd. 515.1896 found 515.1872, [M-H] ${ }^{\top}$ ).

\section{Supplementary Material Available}

Detailed NMR, ESI-TOF MS and MS/MS spectra are given in the Supplementary Data file.

\section{References}

1. Li, J.; Nowak, P.; Otto, S. J. Am. Chem. Soc. 2013, 135, 9222. http://dx.doi.org/10.1021/ja402586c

2. Besenius, P.; Cormack, P.; Ludlow, R.; Otto, S.; Sherrington, D. Chem. Commun. 2008, 2809. http://dx.doi.org/10.1039/B802982B

3. Babine, R.; Bender, S. Chem. Rev. 1997, 97, 1359. http://dx.doi.org/10.1021/cr960370z

4. Luscombe, N.; Austin, S.; Berman, H.; Thornton, J. Genome Biol. 2000, 1, 1. http://dx.doi.org/10.1186/gb-2000-1-1-reviews001

5. Nagai, K. Curr. Opin. Struct. Biol. 1996, 6, 53. http://dx.doi.org/10.1016/S0959-440X(96)80095-9 
6. Fischer, E. Chem. Ber. 1894, 27, 2985.

http://dx.doi.org/10.1002/cber.18940270364

7. Lehn, J.-M. Angew. Chem. Int. Ed. 1990, 29, 1304.

http://dx.doi.org/10.1002/anie.199013041

8. Sun, R.; Xue, C.; Ma, X.; Gao, M.; Tian, H.; Li, Q. J. Am. Chem. Soc. 2013, 135, 5990. http://dx.doi.org/10.1021/ja4016952

9. Klug, A. Angew. Chem.1983, 95, 579. http://dx.doi.org/10.1002/ange.19830950803

10. Klug, A. Angew. Chem. Int. Ed. 1983, 22, 565. http://dx.doi.org/10.1002/anie.198305653

11. Fesik, S.; O’Donnel, T.; Gampe, R.; Olejniczak, E. J. Am. Chem. Soc. 1986, 108, 3165. http://dx.doi.org/10.1021/ja00272a002

12. Piątek, P. Chem. Commun. 2011,47, 4745. http://dx.doi.org/10.1039/C0CC05537A

13. Di Tullio, A.; Reale, S.; De Angelis, F. J. Mass Spectrom. 2005, 40, 845. http://dx.doi.org/10.1002/jms.896

14. Brodbelt, J. S. Int. J. Mass Spectrom. 2000, 200, 57. http://dx.doi.org/10.1016/S1387-3806(00)00302-X

15. Tang, X.-J.; Fred Brewer, C.; Saha, S. Rapid Commun. Mass Spectrom. 1994, 8,750. http://dx.doi.org/10.1002/rcm.1290080918

16. Henning Cederkvist, F.; Zamfir, A.; Bahrke, S.; Eijsink, V.; Sørlie, M.; Peter-Katalinić, J.; Peter, M. Angew. Chem. 2006, 118, 2489. http://dx.doi.org/10.1002/ange.200503168

17. Henning Cederkvist, F.; Zamfir, A.; Bahrke, S.; Eijsink, V.; Sørlie, M.; Peter-Katalinić, J.; Peter, M. Angew. Chem. Int. Ed. 2006, 45, 2429. http://dx.doi.org/10.1002/anie.200503168

18. Bongiorno, D.; Ceraulo, L.; Mele, A.; Panzeri, W.; Selva, A.; Turco Liveri, V. J. Mass Spectrom. 2001, 36, 1189.

http://dx.doi.org/10.1002/jms.226

19. Stone, M.; Franz, A.; Lebrilla, C. J. Am. Soc. Mass Spectrom. 2002, 13, 964. http://dx.doi.org/10.1016/S1044-0305(02)00417-8

20. Osaka, I.; Kondou, M.; Selvapalam, N.; Samal, S.; Kim, K.; Rekharsky, M.; Inoue, Y.; Arakawa, R. J. Mass Spectrom. 2006, 41, 202. http://dx.doi.org/10.1002/jms.978

21. Zhu, W.; Yuan, Y.; Zhou, P.; Zeng, L.; Wang, H.; Tang, L.; Guo, B.; Chen, B. Molecules 2012, 17, 11507. http://dx.doi.org/10.3390/molecules171011507

22. Silva Santos, L.; Knaack, L.; Metzger, J. Int. J. Mass Spectrom. 2005, 246, 84. http://dx.doi.org/10.1016/j.ijms.2005.08.016 
23. Nour, H. F.; López-Periago, A.; Kuhnert, N. Rapid Commun. Mass Spectrom. 2012, 26, 1070 .

http://dx.doi.org/10.1002/rcm.6203

24. Nour, H. F.; Hourani, N.; Kuhnert, N. Org. Biomol. Chem. 2012, 10, 4381.

http://dx.doi.org/10.1039/C2OB25171J

25. Nour, H. F.; Golon, A.; Kuhnert, N. Tetrahedron Lett. 2013, 54, 4139.

http://dx.doi.org/10.1016/j.tetlet.2013.05.085

26. Nour, H. F.; Matei, M.; Bassil, B.; Kortz, U.; Kuhnert, N. Org. Biomol. Chem. 2011, 9, 3258. http://dx.doi.org/10.1039/C0OB00944J

27. Kuhnert, N.; Rossignolo, G.; López-Periago, A. Org. Biomol. Chem. 2003, 1, 1157. http://dx.doi.org/10.1039/B212102F

28. Kuhnert, N.; Patel, C.; Jami, F. Tetrahedron Lett. 2005, 46, 7575. http://dx.doi.org/10.1016/j.tetlet.2005.08.155

29. Kuhnert, N.; López-Periago, A. Tetrahedron Lett. 2002, 43, 3329. http://dx.doi.org/10.1016/S0040-4039(02)00523-3

30. Kuhnert, N.; López-Periago, A.; Rossignolo, G. Org. Biomol. Chem. 2005, 3, 524. http://dx.doi.org/10.1039/B414747M

31. Kuhnert, N.; Straßnig, C.; López-Periago, A. Tetrahedron: Asymmetry 2002, 13, 123. http://dx.doi.org/10.1016/S0957-4166(02)00065-4

32. Kuhnert, N.; Tang, B. Tetrahedron Lett. 2006, 47, 2985. http://dx.doi.org/10.1016/j.tetlet.2006.02.100

33. Kuhnert, N.; Marsh, D.; Nicolau, D. Tetrahedron: Asymmetry 2007, 18, 1648. http://dx.doi.org/10.1016/j.tetasy.2007.07.011

34. Nour, H. F.; Islam, T.; Fernández-Lahore, M.; Kuhnert, N. Rapid Commun. Mass Spectrom. 2012, 26, 2865. http://dx.doi.org/10.1002/rcm.6401

35. Molecular modelling was carried out using HyperChem software (Release 8.0). Hypercube, Inc., $1115 \mathrm{NW}$ 4th Street, Gainesville, F1orida 32601 USA. Trial, version from http://www.hypercube.com

36. J. Stewart, J. Comput. Chem. 1989, 10, 221. http://dx.doi.org/10.1002/jcc.540100208

37. Hunter, C.; Nafees Meah, M.; Sanders, J. J. Chem. Soc., Chem. Commun. 1988, 694. http://dx.doi.org/10.1039/C39880000694

38. Chmielewski, M.; Szumna, A.; Jurczak, J. Tetrahedron Lett. 2004, 45, 8699. http://dx.doi.org/10.1016/j.tetlet.2004.09.135

39. Nour, H. F. The development of novel antibiotics using chemical evolution, Ph.D. Thesis, Jacobs University Bremen, 2012. http://www.jacobs-university.de/phd/files/phd20120904_Nour.pdf

40. Nour, H. F.; Golon, A.; Islam, T.; Fernández-Lahore, M.; Kuhnert, N. Tetrahedron 2013, 69, 11130.

http://dx.doi.org/10.1016/j.tet.2013.11.002 